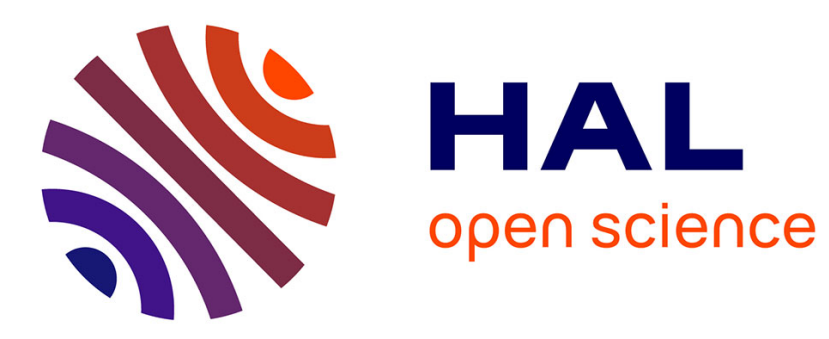

\title{
Streamflow naturalization methods: a review
}

Morgane Terrier, Charles Perrin, Alban de Lavenne, Vazken Andréassian,

Julien Lerat, Jai Vaze

\section{To cite this version:}

Morgane Terrier, Charles Perrin, Alban de Lavenne, Vazken Andréassian, Julien Lerat, et al.. Streamflow naturalization methods: a review. Hydrological Sciences Journal, 2021, 66 (1), pp.12-36. 10.1080/02626667.2020.1839080 . hal-03266329

\section{HAL Id: hal-03266329 \\ https://hal.inrae.fr/hal-03266329}

Submitted on 21 Jun 2021

HAL is a multi-disciplinary open access archive for the deposit and dissemination of scientific research documents, whether they are published or not. The documents may come from teaching and research institutions in France or abroad, or from public or private research centers.
L'archive ouverte pluridisciplinaire HAL, est destinée au dépôt et à la diffusion de documents scientifiques de niveau recherche, publiés ou non, émanant des établissements d'enseignement et de recherche français ou étrangers, des laboratoires publics ou privés. 


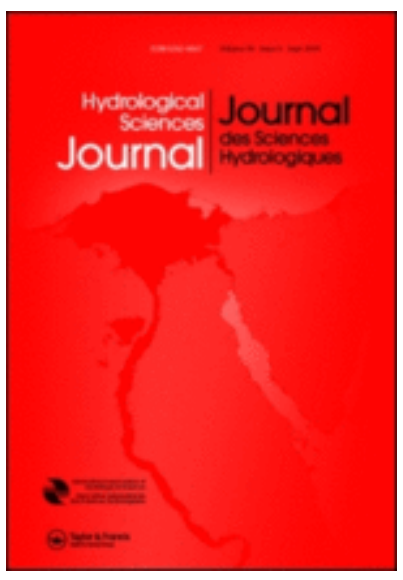

\section{Streamflow Naturalization Methods: a Review}

\begin{tabular}{|r|l|}
\hline Journal: & Hydrological Sciences Journal \\
\hline Manuscript ID & HSJ-2019-0348.R1 \\
\hline Manuscript Type: & Original Article \\
\hline Date Submitted by the & 11 -Jun-2020 \\
\hline Complete List of Authors: & $\begin{array}{l}\text { Terrier, Morgane; Irstea, } \\
\text { Perrin, Charles; Irstea (Cemagref), UR HBAN } \\
\text { De Lavenne, Alban; SMHI } \\
\text { Andréassian, Vazken; Cemagref, Unité de Recherche HBAN, Groupe } \\
\text { Hydrologie } \\
\text { Lerat, Julien; Bureau of Meteorology, Environment and Research - } \\
\text { Forecast Systems } \\
\text { Vaze, Jai; CSIRO, Land and Water }\end{array}$ \\
\hline Keywords: & $\begin{array}{l}\text { Naturalization methods, Influenced catchments, Impacted catchments, } \\
\text { Uncertainty, Hydrological modelling }\end{array}$ \\
\hline
\end{tabular}

\section{SCHOLARONE Manuscripts}


1 Streamflow naturalization methods: a review

2 Morgane Terrier ${ }^{\mathrm{a}}$, Charles Perrin ${ }^{\mathrm{a}^{*}}$, Alban de Lavenne ${ }^{\mathrm{b}}$, Vazken Andréassian ${ }^{\mathrm{a}}$, Julien

3 Lerat $^{\mathrm{c}}$, Jai Vaze ${ }^{\mathrm{d}}$

4 a Université Paris-Saclay, INRAE, UR HYCAR, Antony, France

$5 \quad$ b SMHI, Hydrology department, Norrköping, Sweden

$6{ }^{c}$ Bureau of Meteorology, Canberra, ACT, Australia

$7{ }^{d}$ CSIRO Land and Water, Black Mountain Laboratories, Canberra, ACT, Australia

8 *Corresponding author: charles.perrin@inrae.fr

\section{Abstract}

10 Over the past few decades, several naturalization methods have been developed for 11 removing anthropogenic influences from streamflow time series to the point that 12 naturalized flows are often considered as true natural flows in many studies. However, 


\subsection{Natural, influenced and naturalized flows}

Humans have fundamentally affected the continental hydrological cycle through the impoundment of rivers, land use changes, water extractions and the long-term effect of climate change (Dynesius and Nilsson, 1994; Steffen et al., 2011; Vidal, 2019; Vörösmarty and Sahagian, 2000). Since the 1950s, there has been phenomenal growth of human enterprise, which resulted in an exponential increase in the number of large dams and water consumption (Steffen et al., 2015). These human influences continue to have a significant impact on observed river flows, which will be qualified as "influenced" in the rest of this paper. As highlighted by the Panta Rhei decade launched by the International Association of Hydrological Sciences (IAHS) in 2013, knowledge of the interactions between humans and water remains limited (Montanari et al., 2013). Therefore the natural and anthropogenic parts of the observed flows need to be distinguished (Littlewood and Marsh, 1996). Anthropogenic is understood here as relating to or resulting from the influence of human beings on nature (https://www.merriam-webster.com/dictionary/anthropogenic).

In case of existing human influences upstream of a gauging station, observed flows are generated both by natural processes and human activities. Therefore natural flows cannot be directly measured and must be estimated. Two main types of approaches are adopted to get natural flows:

- Using reference high quality flow observation: Reference Hydrologic Networks (RHNs) have been established in several countries (Burn et al., 2012; Whitfield et al., 2012). The gauging stations are selected for having stable landuse conditions in upstream catchment, no significant regulation, enough record length, active data collection, high data quality and adequate metadata 
(Whitfield et al., 2012). They represent how catchments respond to climate

\subsection{Why do we need natural flows?}

As noted by the Canadian Science Advisory Secretariat (MPO, 2013), the flow of a river is the main variable that connects eco-system components along a river corridor via hydrological, biological, geomorphological, and water quality processes. As a result, natural flow can be typically used as a reference to estimate hydrological response to climate regime, to evaluate the ecological state of a river (Poff et al., 1997) and to estimate the quantity of water available. Here we detail three domains for which natural flows are needed and naturalization methods can therefore be helpful. 


\section{- Ecological impact assessment}

Naturalization methods contribute to the evaluation of anthropogenic impacts on ecosystems. Comparing naturalized streamflows against influenced streamflows provides a way to assess the anthropogenic impact on the natural environment (Poff et al., 1997, Rahman and Bowling, 2018). The degree of alteration corresponds to the difference between naturalized and observed streamflows (Jacobson and Galat, 2008), or the difference between indicators computed on these streamflows (Richter et al., 1996). These indicators include the magnitude of monthly flows, magnitude and duration of annual extreme floods, timing of annual extreme floods, frequency and duration of high and low pulses, and rate and frequency of flow changes (Birkel et al., 2014; De Girolamo et al., 2015; Fantin-Cruz et al., 2015; Fernández et al., 2012; Laizé et al., 2014; Ryo et al., 2015).

The classical approach to quantify the degree of alteration consists in using the observed natural flow from a pre-influence period. However, if these observations are not available or on a too short duration to give a robust estimates of hydrological indicators (Fantin-Cruz et al., 2015), naturalization methods can provide an estimation of natural flow based on data from the influenced period only. Moreover, observed natural flows over the pre-influence period may not be representative of the climate and physical conditions of the influenced period due to natural evolution and variability. Consequently they may not be exploitable for human impact studies. Naturalization methods also make it possible to separate the impact due to anthropogenic pressures (local or regional) and the impact caused by climate change, and to quantify them. The anthropogenic impact corresponds to the difference between the naturalized and observed streamflow during the influenced period. The climatic impact corresponds to a difference between the naturalized flow over the influenced period and the observed 
101 natural flow of an earlier period. As an example, naturalization has been applied in 102 China to quantify climatic and anthropogenic impacts: on the Haihe River basin (Bao et al., 2012; Wang et al., 2013; Zhan et al., 2013), the Yellow River basin (Hu et al., 2015; Li et al., 2007; Wang et al., 2010), the Miyun reservoir (Ma et al., 2010), the Yangtze River basin (Li et al., 2013) and Poyang Lake (Gu et al., 2017), the Laohahe River basin (Jiang et al., 2011) and the Shiyang River basin (Huo et al., 2008). Similarly, in Australia, the CSIRO_(2008) conducted the Sustainable Yields project to assess climate change impacts on the Murray-Darling basin, at a detailed basin scale.

\section{- Climate impact issue}

In a context of climate change, many studies prefer to focus on projections of "natural streamflows", even in heavily influenced rivers, because it would be too complex to address the issues of climate change and water use changes at the same time. Therefore, flow naturalization becomes necessary to serve as a baseline, as well as to calibrate hydrological models. For example, in the case study of the Seine River, Dorrchies_ et (2014) used the naturalized streamflow on the 1990-2011 period to calibrate a model to estimate the future available water resources for the 2046-2065 period. On a larger scale, in the SCENES project (water Scenarios for Europe and Neighbouring States), Laizé et_et_al__(2014) used the naturalized streamflow on the 1961-1990 period as a baseline to estimate the future of freshwater resources for 2040-2069.

\section{- Water resources management}

In many countries, regulations on the authorization of abstractions and discharges into rivers, and on the good ecological status of rivers, are based on naturalized hydrological indicators. The environmental conditions enabling governmental agencies to protect, restore or rehabilitate rivers, can be linked to components of the natural flow regime (Poff et al., 1997). Two of the main approaches to obtain an environmental flow regime 
126 are linked to the natural flow regime (Acreman and Dunbar, 2004): the look-up tables

127 approach is based on the statistical properties of the natural flow regime and the desktop analysis approach is based on the natural seasonality and variability of flows. These methods, failing to have access to observed natural flow, use a naturalized flow regime. In a regulation context, management of water resources is essential to satisfy the supply of drinking water, preserve the ecological status of the aquatic environment, limit the negative consequences of floods and droughts, and provide water for different economic needs such as industry, agriculture, fishing and electricity (European Commission, 1997). In this perspective, naturalized flow can be used to simulate different water management scenarios and the impact of these scenarios on the quantity of available water (Desconnets et al., 1998; Dunn and Ferrier, 1999; Kim and Wurbs, 2011; Maurel et al., 2008; Wurbs, 2006).

Naturalization methods also constitute one of the fundamental element supporting water management policies. For example, the Water Framework Directive typically appeals to natural conditions to define the natural status of a river (Bouleau and Pont, 2015). In France, naturalization methods are used to estimate maximum water extractions sustaining environmental flows (Fabre et Agency developed guidelines to provide naturalized low-flow statistics to enable regulators to make licensing decisions (Bullock et al., 1991; Holmes et al., 2002; Young et al., 2003). These results make it possible, in particular, to define the maximum possible withdrawals to maintain good ecological status (Acreman et al., 2008).

\subsection{Key challenges around naturalization}

Flow naturalization faces several challenges. From a theoretical point of view, a naturalized flow could be defined as a flow observed in the absence of human activities in the catchment upstream of the gauging station. However, the definition of a natural 
status of a catchment may be difficult for various reasons, e.g. when the catchment

152

153 characteristics and the human influences have been co-evolving over a long period. Therefore, there is not always a clear distinction between the influenced period and the pre- or post-influenced periods, which may limit the naturalization process. Obviously, this will be hugely dependent on the geographical region, since some have known the human influence over centuries though others were only influenced over the last few decades.

Another issue lies in the lack of justification in the choice of naturalization methods in many studies. The application of naturalization methods raises hypotheses, in particular in terms of transposition (i.e. transfer of information) in space and time, which seem rarely verified. This may limit the reliability of naturalized flow estimates.

Finally, naturalized flows are often implicitly considered accurate estimates of natural flow. In practice, naturalized flows include uncertainties arising from method assumptions, data and models used. It is therefore important to be transparent about these uncertainties to avoid mis-use of natural flows data when uncertainty is large.

\subsection{Objectives}

The main objective of this article is to provide a review on the issue of flow naturalization. More specifically, this paper intends to (1) provide an overview of the naturalization methods, their assumptions and associated tools, and (2) highlight the scientific issues raised by the application of naturalization methods commonly done in scientific or operational studies.

Establishing a corpus of studies on naturalization methods is not straightforward. Indeed, naturalization methods used to estimate flow series free from anthropogenic influence are rarely the main focus of scientific publications, though they remain a necessary step for many issues detailed above. In addition, there is a quite large 
176 terminology to address naturalization issues (see the discussion in section 3.1).

177 Therefore, the literature review presented in this article is probably not exhaustive 178 though it encompasses already a wide range of aspects. Selected articles in this review 179 dates back to the 1970 s, with a recent increase in publications after 2010, showing a 180 growing interest in this issue in the water management community.

181 This paper is organized as follows. Section 2 lists the main human influences 182 considered in this paper and their potential impact on the natural hydrological cycle.

183 Then section 3 investigates the concept of naturalized flow and how it is interpreted in 184 the literature reviewed. Section 4 presents the main types of naturalization methods with 185 their underlying assumptions and uncertainties. Section 5 discusses scientific and 186 technical issues associated with naturalization methods, with an example in France. 187 Finally section 6 gives some concluding remarks.

\section{Potential impact of anthropogenic influences on streamflow}

189

190

\subsection{Human impacts considered}

A prerequisite for streamflow naturalization is to identify the nature of human impacts and quantify them to determine which influences should be considered in the naturalization process. Figure 1 (Botai et al., 2015) summarizes how human activities potentially affect the different components of the hydrological cycle. The main anthropogenic influences are land cover and land use change, streamflow regulation infrastructure, and withdrawals and discharges associated with different water uses (we did not consider here the impacts of human activities on climate, which ultimately impact water resources). Most of these influences potentially impact several components of the water cycle and so directly or indirectly the observed streamflow. 
200 be interlinked or show counterbalancing effects. For example, in-basin water abstraction

and release may compensate to some extent at the catchment scale, with limited net

impact on mean flow at the yearly scale. However, they may more deeply modify

catchment dynamics at the seasonal or event scale (high or low flows). Other activities

will always strongly impact catchment water yields and hydrological dynamics, e.g.

inter-basin water transfers.

$206 \quad$ [Figure 1 near here]

207

208

209

210

211

212

\subsection{Dams and their associated storage}

Among the 62 studies applying naturalization methods we reviewed, 47 are considering the impact of dams and artificial reservoirs. The hydrological modifications caused by dams have two origins (McCully, 2001): the impacts due to the management of the dam (alternating operations of water storage and release) and the impacts stemming from the ponding effect of the reservoir. The presence of the stagnant water body, created by the dam, modifies several components of the local hydrological cycle, including evaporation and infiltration, and local precipitation for large dams (Degu and Hossain, 2012; Haberlie et al., 2016). It may also strongly modify water quality (Winton et al., 2019). A permanent rise in the water table downstream can be caused by infiltration from the reservoir. The dam operations, consisting of periods of storage and release, regulate water flows in a way generally opposite to natural processes (typically flood alleviation or low-flow augmentation). They also result in various states of the lake behind the dam: for flood protection, the reservoir should be as empty as possible and for potable water supply, the reservoir should be as full as possible (Margat and Andréassian, 2008). From a temporal point of view, dams can cause changes in flow seasonality and temporary fluctuations, especially hydro-power dams. The management 
224 of hydro-power reservoirs will depend on the profitability of electricity generation; for

225

226

227

228

229

230

231

232

233

234

agriculture purposes, it will depend on crop need. Since each dam has specific management rules, the impacts of the dams and their amplitudes are each time specific.

Note that the cumulated effect of dams over a catchment may also be considered. This is often the case when there are many small farm dams spread over a catchment. In that case, this is often much more difficult to access data for each dam and a meta-analysis over all dams may be preferred (Dong et al., 2019; Fowler et al., 2015; Hughes and Mantel, 2010).

\subsection{Water withdrawal}

Water withdrawals refer to the amount of freshwater that is artificially extracted from groundwater or surface water resources. The consumptive use of water corresponds to "the part of water withdrawn that is evaporated, transpired, incorporated into products or crops, consumed by humans or livestock, or otherwise not available for immediate use" (USGS and National Water-Use Science Project, 2019). In our case, water returned to a different catchment than the point of withdrawal (interbasin transfer) is considered a consumptive use. Therefore the quantity of water withdrawn from a river cannot be considered a good indicator of the actual quantitative impact of withdrawals, and the consumed water quantity should be used instead. According to the report of the World Water Development Program (WWAP, 2009), agriculture is the largest consumer of water with $90 \%$ consumption for drip irrigation and $50-60 \%$ for surface irrigation. The energy sector has the smallest consumption ratio on the order of $1-2 \%$. Domestic uses consume between 10 and $20 \%$ of the water withdrawn, and industry between 5 and $10 \%$. These figures, however, remain overall estimates with large variability between regions. Water withdrawal can have a temporal impact because of the time lag between 
248 the time the water is withdrawn and the moment when the amount of water not 249 consumed returns to the system (Kendy and Bredehoeft, 2006).

250 Two sources of water are distinguished: water withdrawn from the groundwater and

\subsection{Water release}

Water releases refer to the amount of water that is artificially brought to rivers. Two cases of water release can be distinguished: water releases originating from a withdrawal on the basin and the releases from an inter-basin water transfer. Inter-basin water transfer corresponds to the artificial withdrawal of water by ditch, canal or pipeline from its source in one basin for use in another (Slabbert, 2007). The streamflow of the receiving basin can consequently be artificially increased. It can also impact the seasonality of river flows. For example, in several rivers in South African, inter-basin transfers aim to counter temporal variability and reduce the economic impact of a localised drought (Blanchon, 2005). In the case of a release following a withdrawal within the catchment, one part of the water withdrawn having been consumed, the 
272 release has a reduced impact on the water resource quantity but an impact on the

273

274

275

276

277 temporality of observed streamflow. In the case where the release place differs from the withdrawal place, release can impact the spatial distribution of water resources.

\subsection{Land use and land cover change}

Human activities can lead to a change in land use and land cover through urbanization, agricultural development, afforestation and deforestation. In the article database, human influences related to land use are taken into account in the naturalization process in only eleven studies, although they are the most pervasive anthropogenic impact (Pagano and Sorooshian, 2005). Changes in land use and land cover have an indirect impact on flow. In modifying the quantity of energy absorbed by the surface, the evaporation rate is impacted and the precipitation rate can also be modified in changing the temperature gradient (Giambelluca, 2005). Groundwater recharge and overland flow are also impacted. Moreover, numerous studies on land use and land cover change and its impact on the hydrological cycle have been carried out in relatively small paired catchments (Stednick, 1996), with results that are difficult to generalize to a larger scale (Siriwardena et al., 2006; Zhang et al., 2018). The particularity of land use change is that modification of the evapotranspiration-runoff relation at the local scale can impact the regional water balance because of changes in atmospheric circulation (Bosmans et al., 2017; Chase et al., 2000; Gash and Nobre, 1997).

\subsection{Combination of human impacts}

In practice, observed flow at gauging stations is potentially influenced by several existing human activities in the basin: industries, energy production at the hydroelectric dam, agriculture, recreational activities (e.g. ski resorts, navigation for pleasure boating) and cities (see illustration in Figure 2). 
297 Flow regulation and direct withdrawal and discharge in rivers lead to a sudden change 298 (typically on a daily basis) in river streamflow, whereas the impacts on the other 299 components of the hydrological cycle can take longer to impact the observed 300 streamflow. The time delay of the impact on the observed flow is also conditioned by 301 the distance between the source of the influence and the gauging station, and by the 302 water pathways. For example, in Figure 2, stations A2 and C are both influenced by the dam's management. The A2 station, directly downstream of the dam, is impacted sooner than station $\mathrm{C}$ due to shorter propagation time.

The importance of the influenced signal contained in the observed streamflow can be conditioned by several factors. Distance plays a role because the intermediate hydrological processes can mitigate the importance of the impact (Mwedzi et al., 2016). Thus, the influence of the dam at station $\mathrm{C}$ is much less than at station $\mathrm{A} 2$, because dam releases will represent a smaller proportion of the total streamflow at station $\mathrm{C}$ than at station A2, due to inflows by the intermediary basin. In the case of basins with multiple influences, there can be compensations of some impacts: dam releases can be planned for agricultural withdrawals downstream, and therefore their impact may not be visible at the catchment outlet, the reservoir can increase groundwater recharge and thus compensate the effects of underground withdrawals in summer (Constantz and Essaid, 2007).

The impact of human activities on flow therefore depends on several factors specific to each basin (type of influence and location, basin characteristics). The following sections present if and how impacts are taken into account in the naturalization process. 


\section{Defining the natural state of the flow regime}

320 In naturalization studies, the purpose is to produce a reference flow regime for 321 influenced rivers. First, the question of what the natural regime of a river corresponds to 322 is addressed, followed by the use and identification of the reference period in studies.

323

324

\subsection{Naturalization terminology}

Examples of scientific definitions of "natural streamflow" or "natural regime" are provided in Table 1. For definitions (D1) and (D3), it is possible to have a natural streamflow despite the presence of anthropogenic factors as long as it does not significantly impact streamflow. Moreover, (D1) and (D2) include the notion of runoff, which can be modified by land use change, without specifying whether it is from a natural or anthropic source. Only (D3), which remains quite comprehensive by referring to "human activity", could take into account this notion of land use and land cover change by human intervention. The first three definitions refer to climate as a variable of the natural regime even though climate change is linked to greenhouse gases emitted by humans. Although (D2) does not refer to the catchment in its natural state, it refers to the drainage network, and thus the aspect of the natural geomorphology of the river. (D4) remains quite general by referring to natural conditions without explaining what they are.

[Table 1 near here]

Although there is no common definition of natural streamflow, we summarise the previous definitions as follows: a naturalized streamflow refers to an estimation of the natural flow under specified conditions of river basin development that includes either no human impact or some defined low level of development (Wurbs, 2006). 
342 In the literature, it appears that the streamflow obtained in naturalization is not 343 systematically called "naturalized streamflow" and may be designated by other words 344 which are not necessarily synonymous. We will present the terms by which some authors refer to naturalized flows and discuss the nuances in the definition of naturalized flow that these terms imply. First, there are the terms referring to the influenced state of the basin such as the terms "regulated" or "influenced" streamflow. Following existing definitions of regulated flow (AFB and Ministère chargé de l'environnement, 2016a; Bureau of Meteorology, 2012; Environmental Protection Agency, 2015; WaterNSW, 2015), an unregulated streamflow corresponds to a natural flow not impacted by artificial flow-regulation structures. The influences of land-use changes are therefore not included. The terms "uninfluenced" and "unimpaired" flow refer to the flow of an undisturbed stream caused by human interventions and whose flows retain their general characteristics (AFB and Ministère chargé de l'environnement, 2016b). The uninfluenced flow thus takes into account a wider field of influence such as the change of land use and land cover. Other terms refer to the natural state of the catchment such as "flow under natural conditions" and "natural flow". The "simulated natural streamflow" encountered in some studies refers to a naturalized streamflow obtained using a hydrological model. The terms of "reconstructed or estimated natural/virgin streamflow" are synonymous with naturalized streamflow. Although all these terms refer to a naturalized flow, they may not reflect the same natural reference. So, the nuances between these terms must not be forgotten to avoid confusion.

\subsection{Determination of the basin's baseline condition}

As illustrated in Figure 3, three periods can be distinguished in naturalization. The 
366 influenced period corresponds to the period when the observed flows are impacted by

367

368 anthropogenic influences. Over this period, where no observation of the natural flow is available, one seeks to estimate natural streamflow using naturalization methods.

[Figure 3 near here]

The pre-influence period serves as the basin's baseline condition and is assumed to correspond to a past period when the observed flow is considered as free of the impact of the anthropogenic influences considered in the naturalization processes. Information from this pre-influence period is used by several naturalization methods. However, in many cases, the influence dates back before flow measurements were made and there is therefore no information on natural flows.

The post-influence period corresponds to the period after the influences considered in the basin has ceased and a return to a natural state, which may be different from the state before the influence. This period is also relevant to serve as a natural reference period if the system has enough time to return to uninfluenced conditions. Obviously, the post-influence period does not exist in catchments under active anthropogenic activities. Studies exploiting the post-influence period mainly focus on sediment dynamics and fauna and flora species after a dam removal (Hart et al., 2002; Kibler et al., 2011; Magirl et al., 2014). Therefore, post-influence periods will not be discussed in this paper, however some comments about the pre-influence period are somewhat transposable to post-influence.

The use of data from the pre-influence and post-influence periods to estimate the natural regime over a later influenced period raises a question about the reversibility of the system: if all activities stopped, would the river be able to return to a natural state that it would have reached if it had never been influenced (Cooper, 2004)? In some cases, the 
390 influence of humans is so old that it has shaped the characteristics of the basin and it

391

392 represents the new natural condition. For example in southern France, the system Neste was created in the $19^{\text {th }}$ century for irrigation purposes. This network of canals strongly impacted the land use of a large number of small catchments, with conditions now that are very different from those that were before (Tardieu, 2008; Villocel, 2002). Still in France, many wetlands were dried out for sanitary of agricultural objectives, like the Marais Poitevin since the beginning of the $18^{\text {th }}$ century, and it would be difficult to come back to the pristine conditions (Godet and Thomas, 2013).

Theoretically, the separation of the pre-influence and influenced periods should match the start of the influence on the basin. In practice, in the case of dam commissioning, as illustrated for the Aube dam (Figure 4), the change on the observed flow time series is abrupt and so the separation is easily identifiable. In other cases, like withdrawals or small farm dams, which may gradually appear in the basin and evolve over time, or in the case of gradual land use and land cover change, the date of implementation of all the influences is rarely accessible and there is generally no abrupt change on the observed flow time series, which complicates the separation dating.

[Figure 4 near here]

In naturalization studies, change-point detection tests (Andréassian et al., 2003; Hubert et al., 1989) are mainly used to distinguish the pre-influence and influenced periods (Bao et al., 2012; Gu et al., 2017; Guo et al., 2014; Hu et al., 2015; Jiang et al., 2011; Wang et al., 2009; Wang et al., 2013; Zhan et al., 2013). The identified break point most often corresponds to a statistically significant change in the observed flow time series, but this break can have an anthropogenic origin (dam, urbanization, etc.), be natural (natural change in the morphology of the river) or stem from climatic variability or a 
414 data problem (change in data measurement devices, etc.). With this method, it is

415 important to underline that anthropogenic disturbances can still exist during the period

416 defined as pre-influence (Jiang et al., 2011) and that these influences can therefore

417 impact the naturalized flows obtained.

\section{Methods to naturalize streamflows}

419

420

421

422

\subsection{Overview on naturalization methods}

We have identified six main naturalization methods in the literature: (1) the reconstitution, (2) water balance, (3) routing, (4) the extension, (5) the paired catchment and (6) regionalization (or neighbourhood) methods. These methods differ mainly by their input data and the underlying models used.

The reconstitution, extension and neighbourhood methods are based on a hydrological model simulating a naturalized streamflow with an estimated set of parameters reflecting the natural hydrological conditions. In reconstitution, failing to have past observations, information on the observed influenced streamflow and the anthropogenic influences are exploited to indirectly estimate the set of parameters representing natural hydrological conditions. In extension, past observations of natural flows on the target catchment are used to estimate the set of parameters reflecting the natural hydrological conditions. In neighbourhood, the observations that exist on neighbouring basins are exploited to estimate the set of parameters. Although these methods use a hydrological model, they rely on different assumptions and data to obtain the model parameter set.

Figure 5 provides a decision tree for the use of the various methods. The starting key question is generally the availability of input data on influences, followed by the availability of data from pre- or post-influenced period, or of regional data. The use of these different data raises hypotheses for the application of the methods. Figure 5 shows 
438 which methods can be applied based on the available data. If all the data are available,

439 all the methods can be applied. If no data is available, one may end up to the conclusion

440 that no flow naturalization is possible (black ellipse on the graph). In that case, one may

441 appeal to hydrological models implemented at the global scale, which do not require

442 local or regional data. However, the reliability of these models at the local scale remains

443 limited. That is why this option will not be further discussed in this review.

444 In the following sections, an explanation of the main hypotheses raised by the 445 naturalization methods is provided in order to identify their application conditions.

446 Figure 6 shows which methods are used in our articles database.

$447 \quad$ [Figure 5 near here]

$448 \quad$ [Figure 6 near here]

$449 \quad 4.2 \quad$ Methods using data on influences

\section{$450 \quad 4.2 .1 \quad$ Water Balance}

451 The Water Balance method consists in decomposing flow into a natural part and an 452 influence part at the scale of the influenced system (typically an artificial reservoir), by 453 removing the volume variation in the river induced by the source of influence, $\Delta \mathrm{V}$, 454 during the time interval $\Delta \mathrm{t}$, from the influenced observed flow, $\mathrm{Q}_{\text {observed, }}$, to obtain the 455 naturalized flow, $Q_{\text {naturalized }}$ (equation 1). The system studied can be a river reach where 456 there is a water withdrawal or release, or a reach downstream of an influence. By 457 convention, in the case of a water discharge, $\Delta \mathrm{V}$ will be negative. In the case of a water 458 withdrawal, $\Delta \mathrm{V}$ will be positive. This method is generally applied at a gauging station 459 located downstream of the influences in the river, although in principle it is also 460 applicable to a fictitious point where flow data obtained through regionalization 461 methods are available. Hydraulic propagation between the influence and the station can 
have an impact on the computation of the naturalized streamflow. The $\Delta \mathrm{V}$ computed at a moment $\mathrm{t}$ will not have an immediate impact on the observed streamflow at the downstream station, but will have an impact at the time $\mathrm{t}+\Delta \mathrm{p}$, where $\Delta \mathrm{p}$ corresponds to the propagation time. If the propagation time is much lower than the study time step, then the propagation effect can be ignored. Otherwise, it is advisable to use a propagation model. The choice of time step will define the hydrological processes to be taken into account and their influences to be considered.

$$
Q_{\text {naturalized }}=Q_{\text {observed }}+\frac{\Delta V}{\Delta t}
$$

The Water Balance method is the most widely used in the studies. Table 2 lists the studies using this method. It appears that this method, mainly constrained by the availability of data, is mostly applied to a daily time step over periods ranging from a few months to several decades. However, if the method is applied over a long period of time, there may be disparities in the quality of the naturalized flows obtained over the entire period. This may be due to the evolution of the quality of the measured flows (Littlewood and Marsh, 1996). In the studies taking into account the influence of dams, it appears that, for the most part, only the impact of dam regulation operations is taken into account (Assani et al., 1999; Kim and Wurbs, 2011; Naik and Jay, 2005; Page et al., 2005; Peters and Prowse, 2001; Yuan et al., 2017). Some studies also take into account evaporation from the reservoirs (Fantin-Cruz et al., 2015; Tongal et al., 2017) and precipitation falling on the reservoirs (Gu et al., 2017), but no studies seem to take into account the underground exchanges induced by the reservoir. For studies taking into account withdrawals, it appears that it is the volume of water consumed that is taken into account in naturalization and not the volume of water withdrawn (Davtalab et al., 2017; Littlewood and Marsh, 1996; Wallace and Pavvloski, 1988; Wurbs, 2006). 
$486 \quad$ [Table 2 near here]

487

488

489

490

491

492

493

494

495

496

497

498

499

500

501

502

503

\subsubsection{Reconstitution method}

The Reconstitution method is based on the exploitation of the influenced observed streamflow and the information available on influences during the influenced period and on the use of hydrological models taking anthropogenic influences explicitly into account. As illustrated in Figure 7, the Reconstitution method consists first in calibrating the hydrological model on the influenced observed streamflow taking into account the anthropogenic influences. Then the set of parameters obtained is used to simulate a naturalized streamflow without taking into account the anthropogenic influences. In cases where the signal of influence in the observed flow is predominant over the natural signal, it is important to ensure that the calibrated parameter set is able to reflect the natural catchment behaviour. Step 1 is common to all studies applying the Reconstitution method, with more or less complex calibration methods depending on the model used and the influence considered. There are some variants of step 2, for the estimation of the naturalized streamflow. One variant corresponds to the case where the model output considered is the time series of the influences. The second step then corresponds to the application of the Water Balance method where the volume variation of the influences is added to the observed streamflow (Dunn and Ferrier, 1999; Maheshwari et al., 1995; Wurbs, 2006). Another more hydraulics-oriented variant, relevant for the semi-distributed and distributed models with an in-stream flow routing, consists at step 2 of propagating the upstream natural streamflow if available ( Kim et al., 2012). In the case of an impact of land use and cover change, in the second step the parameter and input corresponding to influenced land use are changed to correspond to the pre-influenced state (Nobert and Jeremiah, 2012; Shi et al., 2013; Yin et al., 2017; Zhang et al., 2016). 
511

512

513

[Figure 7 near here]

Since studies are often not very explicit in terms of the model calibration with anthropogenic influences, it is difficult to clearly identify which studies apply Reconstitution methods. Table 3 presents a synthesis of the models used in studies applying the Reconstitution method, the time step of the naturalized flow, the influence taken into account as input in the studies and the simulated flow. The impact of dams and reservoirs are often the main issue in Reconstitution studies. This can be explained by the fact that their management can be simulated. The second most studied influence is land use and land cover changes, which are taken into account by physically based hydrological models such as SWAT (see Table 3). The semi-distributed spatial resolution is adopted by most studies. In the case of large catchments, the influences can be localized in space and attenuation of the influences along the river are more accurately considered.

[Table 3 near here]

\subsubsection{Comparison}

The Reconstitution and Water Balance methods are based on the hypothesis that by knowing the impacts of the various influences on the observed flow, it is possible to have a naturalized flow free from these influences. As no study has made a comparison between the Reconstitution method and the Water Balance method, it is not possible to know which one is the most suitable. However, here are a few elements that differentiate these methods and may guide their choice:

- Data availability. The Water Balance method requires time series data on the entire period to naturalize. The advantage of the Reconstitution method is that once the parameter set has been obtained, it is theoretically applicable to other periods. 
536

- Setting up the model. The Water Balance method seems to be easier to apply than the Reconstitution method which requires the implementation of a hydrological model on the basin. However, the use of a hydrological model can facilitate several steps such as estimating the volumes of influences that can be incorporated into the model or estimating travel time. It is difficult to say a priori which method will be easier to apply. This depends primarily on the catchment area and the influences considered.

\subsection{Methods using observation from the pre-influenced period}

\subsubsection{Extension method}

The Extension method is based on the exploitation of observed data of the target catchment from the pre-influence period and on the use of a hydrological model able to simulate the natural streamflow of the target catchment. The required data for the preinfluence period are at least the natural observed streamflow and the input data required by the model. On the influenced period, the input data required to use the model are necessary. The Extension method consists in calibrating the hydrological model on the natural observed streamflow of the pre-influence period and then in using the set of parameters obtained on the influenced period to simulate a naturalized streamflow (Figure 8).

[Figure 8 near here]

Table 4 presents an overview of the studies applying the Extension method and the hydrological models used. The common point of the models is their ability to simulate a natural flow. The models used in these studies show differences in terms of the type and level of complexity. Some studies used empirical models which establish a purely mathematical relationship between natural flow and weather variables over the pre- 
560 influence period. Wen (2009) established a multi-regression model with the 561 precipitation and the maximum temperature data at the monthly time step; Jiang et al. 562 (2011) built a multi-regression model with the precipitation and the potential evapotranspiration; Ahn and Merwade (2014) also take into account the drainage area.

Other studies applied more complex models such as conceptual hydrological models (Chang et al., 2015; Guo et al., 2014; Wang et al., 2013; Zhan et al., 2013), or physical models (Bao et al., 2012; Chang, Zhang, et al., 2015; Jiang et al., 2011; Ma et al., 2010; Wang et al., 2010). Jiang et al. (2011) and Chang et al. (2015), who used models of different types, showed that the results obtained with the two models are comparable. [Table 4 near here]

\subsubsection{Paired catchment method}

This method is explained here but also partly belongs to the family of methods exploiting regional information (see Figure 5). This method is based on the implementation of a statistical flow-rate relationship between the target station to naturalize and natural donor stations over the pre-influence period. The natural donor catchment is generally a catchment that is spatially close to (but not nested in) the target catchment, with similar size. There is no hydrological model involved in this method. This approach is not limited to cases of experimental basins to evaluate land use and land cover changes (Brown et al., 2005). To naturalize the flows of La Grande Rivière in Canada, Hernández-Henríquez et al. (2010) established a flow-rate relation over the pre-influence period by applying a variant of the Hirsh MOVE I method (Hirsch, 1982).

On the Lena River in the Arctic, influenced by a reservoir dam, Ye et al. (2003) established a regression on the pre-influence period between a station downstream of the dam and five natural upstream uninfluenced stations. Smakhtin, (1999) proposed the same principle for catchments in South Africa. In China, Huo et al. (2008) established 
585 flow-rate relationships, including climatic variables (precipitation and temperature), 586 between the uninfluenced upstream and downstream stations. The relation proposed by

\subsubsection{Comparison}

Extension and Paired catchment methods are based on the hypothesis that relations established over the pre-influence period are stationary and remain valid over the influenced period. For the Extension method, running a hydrological model under climatic conditions that are different for the calibration period can generate uncertainties (Coron et al., 2012). The source of these uncertainties can be partly explained by the fact that, in the models, several physical parameters (soil, vegetation, etc.) are related to climatic conditions. The calibration of the model creates an interaction between the parameters and the climatic characteristics of the calibration period. The robustness of the model is usually tested on the pre-influence period by calibrating the model on a sub-period and validating it on another one (Bao et al., 2012; Guo et al., 2014; Jiang et al., 2011; Wang et al., 2010; Wang et al., 2013). For the Paired Catchment method, the limitation is the climatic gradient between the basins, which could lead to the two basins evolving differently. On the pre-influenced period, similar climatic conditions, 
610 landforms, soils, vegetation and hydrological processes between the basins can reduce

611 the uncertainties associated with the natural evolution state of the target catchment

612 (Hernández-Henríquez et al., 2010). These two methods can be distinguished by their

613 level of complexity. The Extension method requires a rainfall-runoff model and

614 meteorological data as input, whereas the paired basins method is simpler because it

615 consists in establishing a relationship between two neighbouring catchments and only

616 requires streamflow measurements. Despite these differences in complexity,

617 Andréassian et al. (2012) showed that the paired basin methods can give better

618 performance than the use of a rainfall-runoff model when the density of gauging 619 stations is quite high.

\section{$620 \quad 4.4$ Methods using regional information}

621

622

623

\subsubsection{Routing modelling}

Routing models can propagate the observed streamflow from upstream to downstream.

In the case where the upstream recorded streamflow is uninfluenced, it can be propagated by a hydraulic model (or other simpler propagation or statistical methods) to obtain a naturalized downstream streamflow.

Table 5 presents studies applying Routing modelling methods to naturalize. The influences taken into account in these studies directly affect flows due to infrastructures built in the river. In these studies, the hydraulic models used assume that the river bed topography is still the same without the dams or levees. The implementation of Routing modelling methods is often time consuming and requires many data to calibrate the hydraulic model (Shiklomanov and Lammers, 2009). This is especially the case when important transmission losses occur and must be accounted for (Hughes, 2019; Pacheco-Guerrero et al., 2017). When the upstream flows are influenced, the flow can 
634 be naturalized and then propagated using a hydraulic model (Peters and Prowse, 2001).

635 Another variant consists in using a hydraulic model that explicitly takes into account the 636 different structures (dam, weir, levee, etc.) that may alter streamflow. The model is first 637 calibrated on the flow conditions of the influenced period. Then, to obtain a naturalized 638 flow, the various obstacles are removed from the propagation model (Ahn et al., 2006; 639 Peters et al., 2006; Wyrick et al., 2009). Wu et al. (2015) assume that the hydraulic 640 propagation has no impact and sum the natural upstream flows to naturalize.

$641 \quad$ [Table 5 near here]

642 643

\subsubsection{Regionalization}

Regionalization methods exploit the similarity between catchments to estimate streamflow. Although mainly used for ungauged or poorly gauged basins, their application in naturalization studies is an interesting option for several reasons. First, the Water Balance and Reconstitution methods require good knowledge and an access to the data used to characterize the influences, whereas regionalization methods are usable on a basin with limited data (Hernández-Henríquez et al., 2010; Ye et al., 2003). Secondly, the principle of the Extension methods is based on the temporal transposability of streamflow. Regionalisation methods can be viewed as a variant based on spatial transposability.

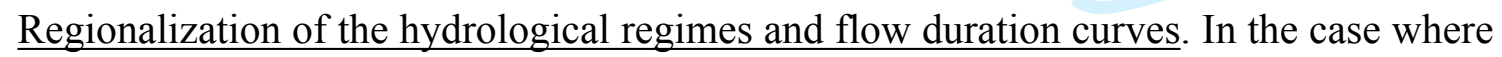
only the flow characteristics of the natural basin's behaviour are investigated and not complete time series are sought, the regionalization of a hydrological regime can be used. For example, in Switzerland, the natural monthly regimes of Alpine basins have been classified into six groups according to the average altitude of the catchments and the proportion of their glacier-covered area. Therefore, due to the physical characteristics of the influenced catchments and an estimate of the average annual flow, 
659 Weingartner and Aschwanden (1994) estimated their natural monthly regime, with an 660 uncertainty ranging from 10 to $20 \%$. In Spanish basins, Fernández et al. (2012) 661 estimated the naturalized monthly flow with a hydrological model at the influenced

stations. Then, to estimate the naturalized regime at a daily time step, they calculated daily distribution coefficients on neighbouring natural stations. These distribution coefficients were then applied to the naturalized monthly flows that had a naturalized daily regime. Here, since the focus is on methods for obtaining naturalized flow time series, the methods of this subsection will not be further discussed. However, they remain used operationally in many countries, in cases where only synthetic streamflow descriptors are needed.

Neighbourhood method. The Neighbourhood method consists in estimating the hydrological model parameters on natural neighbouring basins. The selection criteria for natural neighbouring basins are related to geographical distance or the physical characteristics of the basins (Hrachowitz et al., 2013). This method is not currently used on gauged stations in naturalization studies. However, like the Extension and Reconstitution methods it uses a hydrological model with an alternative approach to estimate the model parameter. It may be of particular interest when there are no existing natural flow data on the pre-influence period nor on the influences themselves during the influenced period.

\subsubsection{Comparison}

In this family, the Routing method seems to be a priori the method giving the best estimate of natural flow since it directly exploits measurements of natural flows upstream of the basins. However, in the case where the intermediate basin has a significant influence on the flow, it may be necessary to also use a hydrological model to simulate the contribution of the intermediate flow (Wyrick et al., 2009). It is also a 
684 complex method to use in the case of large transmission losses between the upstream 685 and downstream station (e.g. in arid regions) (Schreiner-McGraw and Vivoni, 2018).

\section{Discussion}

\subsection{Defining naturalized streamflow}

When discussing the definition of a natural regime, we showed that there is no consensus on what a naturalized flow and the natural state of a basin should exactly refer to. This impacts the choice of the reference period in the various studies. In practice, the definition of naturalized streamflow should be a compromise between:

- Our knowledge of the interactions between human activities and the water cycle and the limit of the definition to be adopted. Since the water cycle is linked to several other environmental cycles (energy, chemistry, sedimentation, etc.), this raises the question of the natural state of these other environmental cycles and their interactions with the water cycle. Typically, the issue of defining a natural reference in the climate or ecological domains has been discussed and results 
from a compromise between knowledge, data availability and objectives in the use of the reference (Brázdil et al., 2005; Davis, 2015; Gatti et al., 2015; Roubicek, 2010).

- A definition not too restrictive to be applicable to a large number of case studies. Ideally, the reference conditions should correspond to minimally disturbed conditions (Stoddard et al., 2006), i.e. conditions where there is no significant anthropogenic disturbance. In practice this would be very constraining because it is difficult nowadays to access data from basins that are not disturbed by human activities. In Europe, there are no data on the natural state of a catchment because the continent has long been densely populated, and the landscapes and land use have been modified by human presence (Stahl et al., 2010). Moreover, in some studies, only the naturalization of major influences is desired. In some cases, the naturalized flow can be obtained by removing a single influence to quantify the role of the influence in the observed flow.

The summary of previous definitions we gave in section 3.1 may meet this compromise. This is actually a key issue when establishing hydrometric reference networks. Since they should be representative of natural flow conditions, the question of the criteria to be met in order to consider the corresponding catchments as natural references is raised (Whitfield et al., 2012). It appears that the definition of conditions vary between national networks. In Canada, where there are many catchments in pristine conditions, criteria are more rigorous whereas the impact of influences on natural flow regimes is visible across much of the UK rivers for instance.

The current perspectives would be to define the naturalized flow as corresponding to a more or less natural state of the basin and to express which influences and associated 
732 impacts are considered in each study. Another perspective is to use a more 733 comprehensive approach, consistent with the definition of naturalized flow chosen, to 734 identify the pre-influence period. In the reviewed studies applying naturalization 735 methods, the methods to identify the reference period are currently limited to change736 point detection tests, which raise several issues concerning the origin of the change737 point. It would also be interesting to have methods to detect a certain level of influence 738 on the basin.

739 Although defining terms appears essential to understand and compare studies, the 740 definition process can lead to a reflection on the role of the influences in the methods 741 and the hypotheses raised. For example, in the case of the Extension method, setting it 742 at a pre-influence period may imply to account for change in land use to obtain the 743 naturalized flow.

\section{$744 \quad 5.2 \quad$ Choice of naturalization methods}

745 By comparing the characteristics of the studies with the choice of the naturalization 746 methods applied, it appears that the same methods are applied on basins with different 747 areas, from the basin scale $\left(100-10,000 \mathrm{~km}^{2}\right)$ to the regional scale $(100,000-1,000,000$ $748 \mathrm{~km}^{2}$ ), and with different influences. Methodological aspects of the studies such as the 749 time step and the length of the available time series to naturalize do not seem to play a 750 major role in the choice. This raises the question of the criteria that can motivate authors 751 to choose one method over another.

\section{$752 \quad 5.2 .1 \quad$ Data availability}

753 From a practical point of view, data availability is the first selection criterion (Table 6), 754 which is also reflected in the decision tree illustrated in Figure 5. Thus, the Water 
755 Balance and Reconstitution methods use data on influences. The Paired Catchment and 756 Neighbourhood methods need data on non-influenced catchments. The Routing 757 modelling method requires a natural upstream flow to propagate it downstream. The 758 Extension and Paired Catchment methods need data on the past observed natural 759 streamflow. It is clear that several of these methods are relatively similar and that they 760 differ only in the tools used. In this section, we will discuss the aspects that can 761 influence the choice of the applied methods.

762 [Table 6 near here]

\subsubsection{Distance between the source of influence and the gauging station}

764 Distance is taken into account by the Water Balance and the Routing modelling methods with the propagation time, and by the Reconstitution methods, which take it into account according to the structure of the model used and the parameters. For the transfer modelling family methods, in the case where intermediate hydrological phenomena such as runoff or river-groundwater exchange have a potential impact on the routed flow, a hydrological model should be used to simulate them.

\subsubsection{Type of influences}

In the transfer modelling family, Routing modelling methods are used only to take into account influences that directly impact the flow, as is the case for dams and withdrawals. For the Water Balance method, all the influences and their associated impact on the hydrological cycle could theoretically be taken into account via the $\Delta \mathrm{V}$. In practice, indirect impacts on river streamflow are easier to take into account with a hydrological model family method.

In the hydrological method family, theoretically the entire impact on the hydrological cycle could be considered. In practice, the type of influences present in the basin seem 
779 to impact the choice of method. In studies that take into account land use and land cover 780 changes in their naturalization process, only Extension and Reconstitution methods are used. The Extension method is calibrated on the basin conditions before the evolution of the cover. The Reconstitution method makes it possible to take the land cover directly into account during the calibration and then modify it. As land use changes indirectly modify the flow, it is easier to take these interactions into account with a hydrological model. For the Regionalization methods, this would require a neighbouring basin with a land cover similar to the influenced basin in its natural state. These methods could be applied on small experimental Paired Catchments (Brown et al., 2005) but do not seem to be applicable to large catchments.

Regionalization methods are applied on catchments which are strongly influenced by dams and other influences. This can be explained by the fact that it is now difficult to access databases with completely uninfluenced catchments. Weingartner and Aschwanden (1994) explain that Regionalization methods are easier to apply in cases where the hydrological conditions encountered are very complex, as in multi-influenced basins. The complexity of the influences and their impact on the catchment could be a limit of the Reconstitution method. For example, in the case where irrigation return flow is taken into account, the difficulty in quantifying them (Dewandel et al., 2008) may lead to eliminating the choice of Reconstitution method.

\subsection{Operational implementation of naturalization methods: the case study on the Rhône basin (France)}

From theory to practice, it is always useful to see the way practitioners implement methods proposed in the scientific literature. We describe a case study from France. In France, one of the objectives of the Law on Water and Aquatic Environments (LEMA in French) of 30 December 2006 is to restore the balance between water supply and 
804 demand. Consequently, studies of "withdrawable" water volumes (i.e. water available

805 for withdraw/human-use) were carried out at the catchment scale in order to determine

806 the quantitative state of water resources and then to propose a preservation strategy of

807 the existing balance or reduce the deficit. These studies include several phases,

808 including an important phase on the identification and quantification of anthropogenic

809 influences and a phase on the estimation of the water resource using naturalization

810 methods. The reports produced at the end of these studies are a useful source of

811 information on the application of naturalization methods in operational contexts.

812 Because low-flow periods are of particular concern, naturalized flows are preferentially

813 obtained at a daily scale to calculate drought indicators.

814 Among the many reports available, we made a selection over 20 basins in the the

815 Rhône-Mediterranean Water Agency district (Appendix 1, figure 9). These reports were

816 generally produced by consulting firms and were chosen here in order to have the

817 widest possible panorama (Appendix 1, Table 7). Naturalization methods were applied

818 on sub-basins from a few dozen to several hundreds of square kilometres.

819 With regard to the choice of methods, the most widely used methods are the Water

820 Balance and the Reconstitution methods. The choice of the methods is not clearly

821 justified but can be explained by several factors. First, all influences in the basin are

822 taken into account. This excludes the Extension method where it is almost impossible to

823 have a period when there is no withdrawal, and the Regionalization method where it is

824 also complicated to have neighbouring basins with no withdrawals. However, a variant

825 of the Neighbourhood method used in an operational context consists in calibrating the

826 hydrological model on the naturalized flow of the upstream influenced sub-basins, and

827 then to use the set of parameters obtained on the influenced downstream basin (CEREG

828 Ingénierie, 2011). Moreover, in these studies considerable preliminary work is 
829 undertaken to identify and quantify the anthropogenic influences present in the basins.

830 This facilitates the application of the Water Balance and Reconstitution methods.

831 The synthesis of these reports also highlights the implementation of hybrid 832 naturalization methods to address data gaps. Given that hydrological indicators are 833 calculated on the naturalized flow series, the times series must be long enough. These 834 hybrid versions are presented as a solution in cases where the observational data on 835 influence and streamflow are too short. One version is to first naturalize the streamflow 836 with the Water Balance method and then to apply the Extension method in calibrating 837 the hydrological model on these naturalized flows. Inversely, the influenced flow time 838 series can be extended with a hydrological model and then be naturalized with the 839 Water Balance method. It should be noted that each addition of steps in the 840 naturalization process is a potential source of uncertainty.

841 In the terms of reference of these studies, authors were requested to clarify the limits 842 and uncertainties related to the naturalization process. The level of reflection is very 843 heterogeneous depending on the studies. It appears that most of the authors were able to 844 identify sources of uncertainty. The main sources of uncertainties cited were the 845 streamflow data, the data on the influence and the climatic data used as model input and 846 model calibration. No study has clearly quantified the global uncertainty of the 847 naturalized streamflow obtained. In the Les Gardons catchment, it was highlighted that 848 a $7 \%$ error on the naturalized flow had an impact on the study conclusions.

\subsection{Level of confidence associated with naturalized streamflow}

850 The previous section on the operational application of naturalization methods in France 851 showed that there is a request on how to assign a level of confidence to naturalized 852 flow. Because naturalized streamflow is used as a reference for many applications (as 
discussed in section 1.2), it is important to quantify the associated uncertainties in order to make robust decisions (Refsgaard et al., 2007). The error associated with naturalized flows is not directly quantifiable because there is no observation of natural flows over the influenced period. The estimation of the confidence in the methods can therefore only be done indirectly. Among the articles analysed, there does not currently seem to be a methodology to evaluate the naturalization process. In this part, we discuss how to indirectly estimate the confidence in results.

\subsubsection{Uncertainties in data}

To estimate which method is the most appropriate, a first reflection can be carried out on the quality of the input data (McMillan et al., 2012). As shown in part 5.2, naturalization methods use different input data which can generate different levels of uncertainty. The main categories of input data are:

- Streamflow time series. We distinguish the streamflow time series corresponding to an observed natural flow and the time series corresponding to an influenced observed flow. The main uncertainties come from the measurement system in place, the operational conditions and the post-processing step to estimate the flow (e.g. the stage-discharge relationship). Usually a postprocessing step corrects the occasional errors. In case of a direct impact, the influenced series can be distinguished from the natural series by the presence of sudden changes in the time series. This implies a more thorough post-treatment to distinguish changes due to measurement errors from those due to anthropogenic influences. Ideally, the measurement system should not change in time. Naik and Jay_(2005) pointed out that flow errors can be much more important at the beginning of the period of record. When choosing a method 
from the hydrological modelling family, questions should be raised on the confidence placed in the natural flow in the past and the observed flow in the beneficial to use the Neighbouring basin method.

- Climatic time series. The main climatic variables used in the studies are precipitation and evapotranspiration. Precipitation estimation at the catchment scale is carried out using interpolation methods of local rainfall measurements. The measurement system put in place must therefore be adapted to the spatial and temporal variability of rainfall events in the basin (Lebecherel, 2015). Since actual evapotranspiration is not measurable at the catchment scale, point evapotranspiration is used most of the time in the studies. However, this potential evapotranspiration corresponds to a model output (Oudin et al., 2005), and therefore includes uncertainties. Precipitation can also be estimated by radar data. In contrast to the raingauge, it is an indirect measurement which is also uncertain.

- Volume time series of human influences. Since the influence measurements are not always available, different techniques and assumptions are used to estimate influence time series. For example, in the naturalization studies examining agricultural withdrawals, the volume time series are estimated based on data reported by farmers (Irwin et al., 1975) or models based on cropping patterns, irrigation water needs and irrigation efficiency (Davtalab et al., 2017; Wallace and Pavvloski, 1988). Uncertainties associated with these processes seem not to be quantified, but it can be assumed that these uncertainties could be greater than for the other input data. It is also difficult in naturalization studies to get sufficient data to characterize all the influences at play on the catchment. Often 
one has data on the major influences (typically dams, abstractions in rivers), but it is harder to quantify the impact of other influences on flows (land use change, groundwater abstractions). This may leave a level of uncertainty difficult to remove in naturalized flow estimates.

A first perspective would be to assess the impact of the quality of these data on the naturalized flow obtained in a sensitivity study (Devak and Dhanya, 2017). Model parameters are sensitive to the errors contained in input data. Several studies have already shown the sensitivity of the models to climate variables (Andréassian et al., 2004; Oudin et al., 2006). For example, Andréassian et al. (2004) showed that having a better estimate of potential evapotranspiration does not give better results. In the case of withdrawable water volume studies in France, there are often strong uncertainties on the influence data, especially on irrigation data. It would therefore have been interesting to see the sensitivity of the calculated hydrological indicators to influence data.

\subsubsection{Uncertainties in model structure}

Model structures can be a source of uncertainties if they are not in line with reality (Pechlivanidis et al., 2011). The model is a simplification of reality and it may be that not all processes are represented. In the Reconstitution method, where the model takes anthropogenic influences into account in the model, it is important to ensure that the structure of the model is adapted to represent the potential impacts of the human activities on the different components of the hydrological cycle. The structure of the Water Balance method can be attractive because of its simplicity, but, during low-flow periods, errors can lead to obtaining abnormally low or even negative flow rates (Agosta, 2007; Littlewood and Marsh, 1996). With the Reconstitution method, the simulated streamflow can be extremely low, which raises questions about its 
926 interpretability, especially in intermittent rivers (De Girolamo et al., 2015).

\section{$927 \quad 5.4 .3 \quad$ Validation of the method's hypothesis}

928 Each naturalization method is based on different assumptions (see section 4). One key

929 issue in all methods is the uncertainty linked to the transfer of information in space and

930 time. This aspect is however not so easy to quantify in the case of naturalization since

931 no natural flow observation is available on the influenced period and standard split

932 sample or proxy-basin approaches (Klemes, 1986) cannot be directly applied.

933 To assess if the method and tools used are appropriate and thus reinforce our confidence

934 in the results, several methods applied in the literature can be used.

935 In the case of the hydrological modelling family, methods are based on the 936 transferability of the parameter set. In fact, there is no single set of parameters that can 937 perfectly reproduce the uninfluenced flow (Beven, 2000). The problem in naturalization 938 is to know which method makes it possible to transfer the parameter sets with the least 939 possible uncertainty. With a temporal transposition, robustness can be assessed using 940 the split-sample test (Coron et al., 2012; Klemes, 1986). This method consists of 941 evaluating the performance obtained over a subperiod different from the calibration 942 period. In the case of a spatial-proximity-transposition, robustness can be assessed using 943 the hydrometrical desert method (Lebecherel et al., 2016). For the Reconstitution 944 method, the uncertainty obtained at calibration on the simulated influenced streamflow 945 can be transferred to the simulated naturalized streamflow.

\section{$946 \quad 6$ Conclusion}

947 Human activities can directly impact the observed flow or several components of the 948 hydrological cycle. These human influences can have an impact at the catchment, 
949 regional or global levels. Consequently, most of the observed flows are influenced. To

950 have a reference to the natural regime of influenced rivers, an increasing number of 951 studies apply different naturalization methods. However, no state of the art on the topic 952 has yet been made. The inventory of the terms to designate a naturalized streamflow 953 shows that there are several definitions considering different human influences. We 954 believe that it would currently be too restrictive to propose a single definition of the 955 naturalized flow. We advise that studies propose a clear definition of the influences and 956 impacts considered by the naturalization process.

957 The main naturalization methods were presented and a classification into three families 958 based on the information they used. Although data availability appears to be the main 959 constraint in the choice of methods to be applied, other criteria play an important role. 960 When intermediate phenomena such as runoff impact the water flow from upstream to 961 downstream, a method from the hydrological modelling family will be more 962 appropriate. The influences and their impacts considered in the naturalization process 963 also lead to questioning the choice of methods and tools used.

964 The example of the application of operational methods shows that the most commonly 965 applied methods for estimating water resources are the Water Balance and 966 Reconstitution methods. This choice is explained by the fact that the authors' goal is to 967 take into account all the influences of the basins and by the difficulty of having access 968 at a completely natural reference over an earlier period or a neighbouring basin. The 969 development of hybrid methods is a consequence of the difficulty of having both an 970 estimate of the natural flow without any influence and a sufficiently long series to 971 calculate robust hydrological indicators. 
972 In these studies of withdrawable water volumes, the uncertainties associated with the 973 naturalization procedure were investigated. It appeared that the authors could identify 974 most sources of uncertainty, but did not quantify the total uncertainty of the naturalized 975 flow obtained. The difficulty in estimating the error associated with naturalized flows is 976 that this can only be done indirectly because the naturalized flow is obtained over a 977 period when there is no direct observation of the natural flow. A first perspective to 978 estimate the confidence of the naturalized flow would be to assess their sensitivity to the 979 input data, knowing that very often these inputs do not correspond to observations. A 980 second perspective would be to indirectly assess the assumptions raised by the methods. 981 Methodologies have been established in the literature to assess the ability of models to 982 transfer a set of parameters spatially or temporally.

\section{$983 \quad 7 \quad$ Acknowledgements}

984 The authors thank the Office français de la biodiversite (OFB) for the financial support 985 of the first author. The Land and Water team of CSIRO is thanked for supporting a 986 research residency of the first author at Canberra, and The Bureau of Meteorology is 987 acknowledged for making data available for this study. Rob Pipunic and Christopher 988 Pickett-Heaps from Bureau of Meteorology are thanked for their comments prior to 989 submission.

\section{References}

991 Acreman, M. C., \& Dunbar, M. J. (2004). Defining environmental river flow requirements - a review. Hydrology and Earth System Sciences, 8(5), 861-876. https://doi.org/10.5194/hess-8-861-2004

Acreman, M., Dunbar, M., Hannaford, J., Mountford, O., Wood, P., Holmes, N., Cowx, I., Noble, R., Extence, C., Aldrick, J., King, J., Black, A., \& Crookall, D. (2008). 
996

997

998

999

1000

1001

1002

1003

1004

1005

1006

1007

1008

1009

1010

1011

1012

1013

1014

1015

1016

1017

1018

1019

1020

Developing environmental standards for abstractions from UK rivers to implement the EU Water Framework Directive / Développement de standards environnementaux sur les prélèvements d'eau en rivière au Royaume Uni pour la mise en œuvre de la directive cadre sur l'eau de l'Union Européenne. Hydrological Sciences Journal, 53(6), 1105-1120. https://doi.org/10.1623/hysj.53.6.1105

AFB, \& Ministère chargé de l'environnement. (2016a). Débit contrôlé - Glossaire sur l'eau [Site de Eaufrance]. Glossaire Sur l'eau.

http://www.glossaire.eaufrance.fr/fr/concept/d\%C3\%A 9 bitcontr\% $\%$ C3\%B41\%C3\%A9

AFB, \& Ministère chargé de l'environnement. (2016b). Débit influencé - Glossaire sur l'eau [Site de Eaufrance]. Glossaire Sur l'eau. http://www.glossaire.eaufrance.fr/fr/concept/d\%C3\%A9bit-influenc\%C3\%A9

Agosta, C. (2007). Naturalisation des débits et modélisation hydrologique sur des sousbassins versant de la Garonne à Lamagistère (in French) (Mémoire de Master 2 Sciences de l'Univers, Environnement, Ecologie - Parcours Hyrologiehydrogéologie, Université Pierre et Marie Curie, Paris, Laboratoire National en Hydraulique et Environnement, EDF Recherche et développement, Chatou. /; p. 51). EDF.

Ahn, C., Johnston, D. M., Sparks, R. E., \& White, D. C. (2006). Analysis of Naturalization Alternatives for the Recovery of Moist-soil Plants in the Floodplain of the Illinois River. Hydrobiologia, 565(1), 217-228.

Ahn, K.-H., \& Merwade, V. (2014). Quantifying the relative impact of climate and human activities on streamflow. Journal of Hydrology, 515, 257-266. https://doi.org/10.1016/j.jhydrol.2014.04.062 
Andréassian, V., Lerat, J., Le Moine, N., \& Perrin, C. (2012). Neighbors : Nature's own 1022

Artelia Eau et Environnement, \& Maison régionale de l'Eau. (2012a). Etudes d'estimation des volumes prélevables globaux - Sous bassin versant de la Drôme des collines (in french) (p. 262). Agence de l'Eau Rhône Méditerranée et Corse. http://www.rhone-mediterranee.eaufrance.fr/docs/gestionquantitative/EEVPG/Drome-descollines/EVP_Drome_collines_rapport_juillet2012.pdf

Artelia Eau et Environnement, \& Maison régionale de l'Eau. (2012b). Etudes d'estimation des volumes prélevables globaux - sous bassin versant de la Galaure (in french) (p. 218). Agence de l'Eau Rhône Méditerranée et Corse. http://www.rhone-mediterranee.eaufrance.fr/docs/gestionquantitative/EEVPG/Galaure/EVP_Galaure_rapport_juillet2012.pdf

Assani, A. A., Petit, F., \& Mabille, G. (1999). Analyse des débits de la Wache aux barrages de Butgenbach et de Robertville (Ardenne belge). Bulletin de La Société Géographique de Liège, 36, 17-30. 
1045 Bao, Z., Zhang, J., Wang, G., Fu, G., He, R., Yan, X., Jin, J., Liu, Y., \& Zhang, A.

1046

1047

1048

1049

1050

1051

1052

1053

1054

1055

1056

1057

1058

1059

1060

1061

1062

1063

1064

1065

1066

1067

1068

1069 (2012). Attribution for decreasing streamflow of the Haihe River basin, northern China: Climate variability or human activities? Journal of Hydrology, 460-461, 117-129. https://doi.org/10.1016/j.jhydrol.2012.06.054

Beven, K. (2000). Uniqueness of place and process representations in hydrological modelling. Hydrology and Earth System Sciences, 4(2), 203-213. https://doi.org/10.5194/hess-4-203-2000

Birkel, C., Soulsby, C., Ali, G., \& Tetzlaff, D. (2014). Assessing the cumulative impacts of hydropower regulation on the flow characteristics of a large atlantic salmon river system. River Research and Applications, 30(4), 456-475. https://doi.org/10.1002/rra.2656

Blanchon, D. (2005). Enjeux territoriaux et impacts environnementaux des transferts d'eau inter bassins en Afrique du Sud. La Houille Blanche, 5, 97-100. https://doi.org/10.1051/lhb:200505010

Bosmans, J. H. C., van Beek, L. P. H., Sutanudjaja, E. H., \& Bierkens, M. F. P. (2017). Hydrological impacts of global land cover change and human water use. Hydrology and Earth System Sciences, 21(11), 5603-5626. https://doi.org/10.5194/hess-21-5603-2017

Botai, C., Botai, O. J., Muchuru, S., \& Ngwana, I. (2015). Hydrometeorological Research in South Africa: A Review. Water, 7(4), 1580-1594. https://doi.org/10.3390/w7041580

Bouleau, G., \& Pont, D. (2015). Did you say reference conditions? Ecological and socio-economic perspectives on the European Water Framework Directive. Environmental Science \& Policy, 47, 32-41. https://doi.org/10.1016/j.envsci.2014.10.012f 
Brázdil, R., Pfister, C., Wanner, H., Von Storch, H., \& Luterbacher, J. (2005).

1071

1072 Historical Climatology In Europe - The State Of The Art. Climatic Change, 70(3), 363-430. https://doi.org/10.1007/s10584-005-5924-1

BRL Ingénierie. (2011). Détermination des volumes prélevables maximum sur le bassin versant de la Cèze. Rapport de phase 2: Analyse de la ressource en eau. Rapport final (in french). (p. 89). Agence de l'Eau Rhône Méditerranée et Corse. http://www.rhone-mediterranee.eaufrance.fr/docs/gestionquantitative/EEVPG/Ceze/EVP_Ceze_rapport-phase2_mars2011.pdf

BRL Ingénierie. (2012). Etudes d'estimation des volumes prélevables globaux - Sous bassin versant de l'Yzeron - Phase 3: Impact des prélèvements et quantification des ressources existantes (in french) (p. 99). Agence de l'Eau Rhône Méditerranée et Corse. http://www.rhonemediterranee.eaufrance.fr/docs/gestionquantitative/EEVPG/Yseron/EVP_Yzeron_Ph3_2012.pdf

BRL Ingénierie. (2013). Etudes d'estimation des volumes prélevables globaux - Sous bassin versant du Garon - Phase 1 - Rapport B (in french) (p. 124). Agence de l’Eau Rhône Méditerranée et Corse. http://www.rhonemediterranee.eaufrance.fr/docs/gestionquantitative/EEVPG/Garon/EVP_garon_rapport_phase1B_janvier2013.pdf BRL Ingénierie. (2014). Etude de détermination des volumes prélevables - Sous bassin versant des 3 rivières - Rapport de phase 3 (p. 146). Agence de l'Eau Rhône Méditerranée et Corse. http://www.rhonemediterranee.eaufrance.fr/docs/gestionquantitative/EEVPG/Cance/EVP_Cance_rapport_phase3_fevrier2014.pdf 
1094 BRL Ingénierie. (2015). Gestion quantitative de la ressource en eau du bassin versant

1095

1096

1097

1098

1099

1100

1101

1102

1103

1104

1105

1106

1107

1108

1109

1110

1111

1112

1113

1114

1115

1116

1117

1118 des Gardons - Etude des volumes prélevables (in french) (p. 274). Agence de l’Eau Rhône Méditerranée et Corse. http://www.rhonemediterranee.eaufrance.fr/docs/gestionquantitative/EEVPG/Gardons/EVP_Gardons_Rapport_01122015.pdf

Brown, A. E., Zhang, L., McMahon, T. A., Western, A. W., \& Vertessy, R. A. (2005). A review of paired catchment studies for determining changes in water yield resulting from alterations in vegetation. Journal of Hydrology, 310(1-4), 28-61. https://doi.org/10.1016/j.jhydrol.2004.12.010

Bullock, A., Gustard, A., Irving, K., \& Young, A. (1991). Low Flow Estimation in Artificially Influenced Catchments (NRA R \& D Project 257; p. 73). NRA, Institute of Hydrology.

Bureau of Meteorology. (2012). Australian Water Information Dictionary - Water status: National Water Account 2012-2015 - line item 1.3 - regulated river. Australian Government - Bureau of Meteorology. http://www.bom.gov.au/water/awid/product-water-status-national-wateraccount-2012-2015.shtml

Burn, D. H., Hannaford, J., Hodgkins, G. A., Whitfield, P. H., Thorne, R., \& Marsh, T. (2012). Reference hydrologic networks II. Using reference hydrologic networks to assess climate-driven changes in streamflow. Hydrological Sciences Journal, 57(8), 1580-1593. https://doi.org/10.1080/02626667.2012.728705

Cabinet Reilé. (2012). Etude de détermination des volumes prélevables dans le sousbassin de la Savoureuse - Rapport d'étape phase III (in french) (p. 86). Agence de l'Eau Rhône Méditerranée et Corse. http://www.rhonemediterranee.eaufrance.fr/docs/gestion- 
1119

1120

1121

1122

1123

1124

1125

1126

1127

1128

1129

1130

1131

1132

1133

1134

1135

1136

1137

1138

1139

1140

1141

1142

quantitative/EEVPG/Savoureuse/EVP_savoureuse_rapport_phase3_aout2012.pd $\mathrm{f}$

CEREG Ingénierie. (2011). Etudes d'estimation des volumes prélevables globaux - Sous bassin versant de l'Asse - Rapport définitif phase 3 (in french) (No. M09067; p. 77). Agence de l'Eau Rhône Méditerranée et Corse. http://www.rhonemediterranee.eaufrance.fr/docs/gestionquantitative/EEVPG/Asse/EVP_Asse_rapport-phases3_oct2011.pdf

CEREG Ingénierie, Idée Eaux, Lisode, Hydriad, \& Brigitte Lambey. (2013). Etudes d'estimation des volumes prélevables globaux - Sous bassin versant du Lez Rapport de phase 3 (in french) (p. 115). Agence de l'Eau Rhône Méditerranée et Corse. http://www.rhone-mediterranee.eaufrance.fr/docs/gestionquantitative/EEVPG/lez/EVP_lez_rapport_phase3_janvier2013.pdf

Chang, J., Wang, Y., Istanbulluoglu, E., Bai, T., Huang, Q., Yang, D., \& Huang, S. (2015). Impact of climate change and human activities on runoff in the Weihe River Basin, China. Quaternary International, 380-381, 169-179. https://doi.org/10.1016/j.quaint.2014.03.048

Chang, J., Zhang, H., Wang, Y., \& Zhu, Y. (2015). Assessing the impact of climate variability and human activity to streamflow variation. Hydrology and Earth System Sciences Discussions, 12(6), 5251-5291. https://doi.org/10.5194/hessd$12-5251-2015$

Chase, T. N., Pielke Sr, R. A., Kittel, T. G. F., Nemani, R. R., \& Running, S. W. (2000). Simulated impacts of historical land cover changes on global climate in northern winter. Climate Dynamics, 16(2-3), 93-105. https://doi.org/10.1007/s003820050007 
1143 Constantz, J., \& Essaid, H. (2007). Influence of groundwater pumping on streamflow

1144

1145

1146

1147

1148

1149

1150

1151

1152

1153

1154

1155

1156

1157

1158

1159

1160

1161

1162

1163

1164

1165

1166

1167 restoration following upstream dam removal. Hydrological Processes, 21(21), 2823-2834. Scopus. https://doi.org/10.1002/hyp.6520

Cooper, R. (2004). Natural flow estimates for streams in the Klamath basin. (Report SW $04-001 ;$ p. 245). State of Oregon, Water Resources Department.

Coron, L., Andréassian, V., Perrin, C., Lerat, J., Vaze, J., Bourqui, M., \& Hendrickx, F. (2012). Crash testing hydrological models in contrasted climate conditions: An experiment on 216 Australian catchments. Water Resources Research, 48(5). Scopus. https://doi.org/10.1029/2011WR011721

CSIRO. (2008). Water availability in the Murray-Darling Basin. A report to the Australian Government from the CSIRO Murray-Darling Basin Sustainable Yields Project. (p. 67). CSIRO. https://publications.csiro.au/rpr/download?pid=legacy:530\&dsid=DS1

Davis, J. (2015). The 30-year "baseline" and the reality of climate change. Weather, 70(6), 190-190. https://doi.org/10.1002/wea.2502

Davtalab, R., Mirchi, A., Khatami, S., Gyawali, R., Massah, A., Farajzadeh, M., \& Madani, K. (2017). Improving Continuous Hydrologic Modeling of Data-Poor River Basins Using Hydrologic Engineering Center's Hydrologic Modeling System: Case Study of Karkheh River Basin. Journal of Hydrologic Engineering, 22(8), 05017011. https://doi.org/10.1061/(ASCE)HE.19435584.0001525

De Girolamo, A. M., Lo Porto, A., Pappagallo, G., \& Gallart, F. (2015). Assessing flow regime alterations in a temporary river - The River Celone case study. Journal of Hydrology and Hydromechanics, 63(3), 263-272. Scopus. https://doi.org/10.1515/johh-2015-0027 
1168

1169

1170

1171

1172

1173

1174

1175

1176

1177

1178

1179

1180

1181

1182

1183

1184

1185

1186

1187

1188

1189

1190

1191

1192

Degu, A. M., \& Hossain, F. (2012). Investigating the mesoscale impact of artificial reservoirs on frequency of rain during growing season: dams and rainfall frequency. Water Resources Research, 48(5). https://doi.org/10.1029/2011WR010966

Département des Alpes-Maritimes. (2013). Etude de détermination des volumes prélevables - Bassin versant du Loup - Rapport de phase 3 (in french) (p. 69). Agence de l'Eau Rhône Méditerranée et Corse. http://www.rhonemediterranee.eaufrance.fr/docs/gestionquantitative/EEVPG/Loup/EVP_Loup_rapport_phase3_nov2013.pdf

Desconnets, J. C., Diallo, A., Traore, O., Chene, J. M., \& Morin, G. (1998). Exemple d'application du modèle CEQUEAU-ONU: Évaluation de l'impact des aménagements sur les écoulements de la rivière Nakambé, Burkina Faso. IAHSAISH Publication, 252, 375-385.

Devak, M., \& Dhanya, C. T. (2017). Sensitivity analysis of hydrological models: review and way forward. Journal of Water and Climate Change, 8(4), 557-575.

Dewandel, B., Gandolfi, J.-M., De Condappa, D., \& Ahmed, S. (2008). An efficient methodology for estimating irrigation return flow coefficients of irrigated crops at watershed and seasonal scale. Hydrological Processes: An International Journal, 22(11), 1700-1712. https://doi.org/10.1002/hyp.6738

Dong, N., Yu, Z., Yang, C., Yang, M., \& Wenzhuo, W. (2019). Hydrological impact of a reservoir network in the upper Gan River Basin, China. Hydrological Processes, 33(12), 1709-1723. https://doi.org/10.1002/hyp.13433

Dorchies, D., Thirel, G., Jay-Allemand, M., Chauveau, M., Dehay, F., Bourgin, P.-Y., Perrin, C., Jost, C., Rizzoli, J.-L., Demerliac, S., \& Thépot, R. (2014). Climate change impacts on multi-objective reservoir management: case study on the 
1193

1194

\section{5}

1196

1197

1198

1199

1200

1201

1202

1203

1204

1205

1206 Seine River basin, France. International Journal of River Basin Management, 12(3), 265-283. https://doi.org/10.1080/15715124.2013.865636

Dunn, S. M., \& Ferrier, R. C. (1999). Natural flow in managed catchments: A case study of a modelling approach. Water Research, 33(3), 621-630. https://doi.org/10.1016/S0043-1354(98)00268-1

Dynesius, M., \& Nilsson, C. (1994). Fragmentation and Flow Regulation of River Systems in the Northern Third of the World. Science, 266(5186), 753-762. https://doi.org/10.1126/science.266.5186.753

Environmental Protection Agency. (2015). Definition and Characteristics of Low Flows from DFLOW - Design Flows: Definitions and Methods. United States Environmental Protection Agency. https://www.epa.gov/waterdata/definitionand-characteristics-low-flows-dflow\#methods

European Commission. (1997). Avis du Comité des régions sur la “Communication de la Commission au Conseil et au Parlement européen sur la politique communautaire dans le domaine de l'eau'. Journal Officiel Des Communautés Européennes C 34/30, 30-33.

Fantin-Cruz, I., Pedrollo, O., Girard, P., Zeilhofer, P., \& Hamilton, S. K. (2015). Effects of a diversion hydropower facility on the hydrological regime of the Correntes River, a tributary to the Pantanal floodplain, Brazil. Journal of Hydrology, 531, 810-820. https://doi.org/10.1016/j.jhydrol.2015.10.045

Fernández, J. A., Martínez, C., \& Magdaleno, F. (2012). Application of indicators of hydrologic alterations in the designation of heavily modified water bodies in Spain. Environmental Science \& Policy, 16, 31-43. https://doi.org/10.1016/j.envsci.2011.10.004 
1217 Fowler, K., Morden, R., Lowe, L., \& Nathan, R. (2015). Advances in assessing the

1218

1219

1220

1221

1222

1223

1224

1225

1226

1227

1228

1229

1230

1231

1232

1233

1234

1235

1236

1237

1238

1239

1240 impact of hillside farm dams on streamflow. Australasian Journal of Water Resources, 19(2), 96-108. https://doi.org/10.1080/13241583.2015.1116182

Gash, J. H. C., \& Nobre, C. A. (1997). Climatic Effects of Amazonian Deforestation: Some Results from ABRACOS. Bulletin of the American Meteorological Society, 78(5), 823-830. https://doi.org/10.1175/15200477(1997)078<0823:CEOADS $>2.0 . \mathrm{CO} ; 2$

Gatti, G., Bianchi, C. N., Parravicini, V., Rovere, A., Peirano, A., Montefalcone, M., Massa, M., \& Morri, C. (2015). Ecological Change, Sliding Baselines and the Importance of Historical Data: Lessons from Combing Observational and Quantitative Data on a Temperate Reef Over 70 Years. Plos One, 10(2). https://doi.org/10.1371/journal.pone.0118581

Giambelluca, T. W. (2005). 189: Land Use and Water Resources Under a Changing Climate. In Encyclopedia of Hydrological Sciences (Wiley-Blackwell, Vol. 5, pp. 2931-2937). Malcolm G. Anderson.

GINGER Environnement \& Infrastructures. (2012a). Etude de détermination des volumes prélevables - Bassin versant de l'Agly - Phases 1, 2 et 3 - Bilan et impact des prélèvements; Quantification des ressources (in french) (p. 304). Agence de 1'Eau Rhône Méditerranée et Corse. http://www.rhonemediterranee.eaufrance.fr/docs/gestionquantitative/EEVPG/agly/EVP_Agly_rapport_phase1a3_janv2012.pdf

GINGER Environnement \& Infrastructures. (2012b). Etude de détermination des volumes prélevables - Bassin versant du Vidourle - Phase 1, 2 et 3 (in french) ( $\mathrm{p}$. 290). Agence de l'Eau Rhône Méditerranée et Corse. http://www.rhone- 
1241

1242

1243

1244

1245

1246

1247

1248

1249

1250

1251

1252

1253

1254

1255

1256

1257

1258

1259

1260

1261

1262

1263

1264

1265

mediterranee.eaufrance.fr/docs/gestion-

quantitative/EEVPG/Vidourle/EVP_Vidourle_rapport_phase1a3_oct2012.pdf

Godet, L., \& Thomas, A. (2013). Three centuries of land cover changes in the largest French Atlantic wetland provide new insights for wetland conservation. Applied Geography, 42, 133-139. https://doi.org/10.1016/j.apgeog.2013.05.011

Gosain, A. K., Rao, S., Srinivasan, R., \& Reddy, N. G. (2005). Return-flow assessment for irrigation command in the Palleru river basin using SWAT model. Hydrological Processes, 19(3), 673-682. https://doi.org/10.1002/hyp.5622

Gu, C., Mu, X., Gao, P., Zhao, G., Sun, W., \& Li, P. (2017). Effects of climate change and human activities on runoff and sediment inputs of the largest freshwater lake in China, Poyang Lake. Hydrological Sciences Journal, 62(14), 2313-2330. https://doi.org/10.1080/02626667.2017.1372856

Guo, Y., Li, Z., Amo-Boateng, M., Deng, P., \& Huang, P. (2014). Quantitative assessment of the impact of climate variability and human activities on runoff changes for the upper reaches of Weihe River. Stochastic Environmental Research and Risk Assessment, 28(2), 333-346. https://doi.org/10.1007/s00477013-0752-8

Haberlie, A. M., Ashley, W. S., Fultz, A. J., \& Eagan, S. M. (2016). The effect of reservoirs on the climatology of warm-season thunderstorms in Southeast Texas, USA: reservoirs and thunderstorms. International Journal of Climatology, 36(4), 1808-1820. https://doi.org/10.1002/joc.4461

Hart, D. D., Johnson, T. E., Bushaw-Newton, K. L., Horwitz, R. J., Bednarek, A. T., Charles, D. F., Kreeger, D. A., \& Velinsky, D. J. (2002). Dam removal: challenges and opportunities for ecological research and river restoration: we develop a risk assessment framework for understanding how potential responses 
1266

1267

1268

1269

1270

1271

1272

1273

1274

1275

1276

1277

1278

1279

1280

1281

1282

1283

1284

1285

1286

1287

1288

1289

1290

to dam removal vary with dam and watershed characteristics, which can lead to more effective use of this restoration method. AIBS Bulletin, 52(8), 669-682.

Hernández-Henríquez, M. A., Mlynowski, T. J., \& Déry, S. J. (2010). Reconstructing the natural streamflow of a regulated river: A case study of la grande rivière, Québec, Canada. Canadian Water Resources Journal, 35(3), 301-316. Scopus. https://doi.org/10.4296/cwrj3503301

Hirsch, R. M. (1979). An Evaluation of Some Record Reconstruction Techniques. Water Resources Management, 15(6), 1781-1790. https://doi.org/10 $.1029 /$ WR015i006p01781

Hirsch, R. M. (1982). A comparison of four streamflow record extension techniques. Water Resources Research, 18(4), 1081-1088. Scopus. https://doi.org/10.1029/WR018i004p01081

Holmes, M. G. R., Young, A. R., Gustard, A., \& Grew, R. (2002). A region of influence approach to predicting flow duration curves within ungauged catchments. Hydrology and Earth System Sciences, 6(4), 721-731. https://doi.org/10.5194/hess-6-721-2002

Hrachowitz, M., Savenije, H. H. G., Blöschl, G., McDonnell, J. J., Sivapalan, M., Pomeroy, J. W., Arheimer, B., Blume, T., Clark, M. P., Ehret, U., Fenicia, F., Freer, J. E., Gelfan, A., Gupta, H. V., Hughes, D. A., Hut, R. W., Montanari, A., Pande, S., Tetzlaff, D., ... Cudennec, C. (2013). A decade of Predictions in Ungauged Basins (PUB)—a review. Hydrological Sciences Journal, 58(6), 1198-1255. https://doi.org/10.1080/02626667.2013.803183

Hu, Z., Wang, L., Wang, Z., Hong, Y., \& Zheng, H. (2015). Quantitative assessment of climate and human impacts on surface water resources in a typical semi-arid watershed in the middle reaches of the Yellow River from 1985 to 2006. 
1291

1292

1293

1294

1295

1296

1297

1298

1299

1300

1301

1302

1303

1304

1305

1306

1307

1308

1309

1310

1311

1312

1313

1314

International Journal of Climatology, 35(1), 97-113.

https://doi.org/10.1002/joc.3965

Hubert, P., Carbonnel, J. P., \& Chaouche, A. (1989). Segmentation des séries hydrométéorologiques - application à des séries de précipitations et de débits de l'afrique de l'ouest. Journal of Hydrology, 110(3-4), 349-367. https://doi.org/10.1016/0022-1694(89)90197-2

Hughes, D. A. (2019). A simple approach to estimating channel transmission losses in large South African river basins. Journal of Hydrology: Regional Studies, 25. https://doi.org/10.1016/j.ejrh.2019.100619

Hughes, D. A., \& Mantel, S. K. (2010). Estimating the uncertainty in simulating the impacts of small farm dams on streamflow regimes in South Africa. Hydrological Sciences Journal, 55(4), 578-592. https://doi.org/10.1080/02626667.2010.484903

Huo, Z., Feng, S., Kang, S., Li, W., \& Chen, S. (2008). Effect of climate changes and water-related human activities on annual stream flows of the Shiyang river basin in arid north-west China. Hydrological Processes, 22(16), 3155-3167. https://doi.org/10.1002/hyp.6900

Irwin, R. W., Dickinson, W. T., \& Lammers, W. (1975). Model for the determination of the natural streamflow of Venison Creek. Canadian Agricultural Engineering, 17(1).

ISL. (2011). Etude de détermination des volumes prélevables - Bassin versant du Doux - Rapport de phase 3 (in french) (p. 87). Agence de l'Eau Rhône Méditerranée et Corse. http://www.rhone-mediterranee.eaufrance.fr/docs/gestionquantitative/EEVPG/Doux/EVP_Doux_rapport_phase3_janv2011.pdf 
1315 Jacobson, R. B., \& Galat, D. L. (2008). Design of a naturalized flow regime - an

1316

1317

1318

1319

1320

1321

1322

1323

1324

1325

1326

1327

1328

1329

1330

1331

1332

1333

1334

1335

1336

1337

1338

1339 example from the Lower Missouri River, USA. Ecohydrology, 1, 81-104. https://doi.org/DOI: 10.1002/eco.9

Jiang, S., Ren, L., Yong, B., Singh, V. P., Yang, X., \& Yuan, F. (2011). Quantifying the effects of climate variability and human activities on runoff from the Laohahe basin in northern China using three different methods. Hydrological Processes, 25(16), 2492-2505. https://doi.org/10.1002/hyp.8002

Jiongxin, X. (2005). The Water Fluxes of the Yellow River to the Sea in the Past 50 Years, in Response to Climate Change and Human Activities. Environmental Management, 35(5), 620-631. https://doi.org/10.1007/s00267-004-3094-y

Kendy, E., \& Bredehoeft, J. D. (2006). Transient effects of groundwater pumping and surface-water-irrigation returns on streamflow: transient effects of groundwater stress. Water Resources Research, 42(8). https://doi.org/10.1029/2005WR004792

Kibler, K., Tullos, D., \& Kondolf, M. (2011). Evolving Expectations of Dam Removal Outcomes: Downstream Geomorphic Effects Following Removal of a Small, Gravel-Filled Dam. JAWRA Journal of the American Water Resources Association, 47(2), 408-423. https://doi.org/10.1111/j.1752-1688.2011.00523.x

Kim, N. W., Lee, J. E., \& Kim, J. T. (2012). Assessment of Flow Regulation Effects by Dams in the Han River, Korea, on the Downstream Flow Regimes Using SWAT. Journal of Water Resources Planning and Management, 138(1), 24-35. https://doi.org/10.1061/(ASCE)WR.1943-5452.0000148

Kim, T. J. (2015). Generation of daily naturalized flow at ungaged control points. Journal of Water Supply: Research and Technology - AQUA, 64(3), 354-364. Scopus. https://doi.org/10.2166/aqua.2015.096 
1340 Kim, T. J., \& Wurbs, R. A. (2011). Development of monthly naturalized flow using

1341

1342

1343

1344

1345

1346

1347

1348

1349

1350

1351

1352

1353

1354

1355

1356

1357

1358

1359

1360

1361

1362

1363 Water Rights Analysis Package (WRAP)-based methods. KSCE Journal of Civil Engineering, 15(7), 1299-1307. https://doi.org/10.1007/s12205-011-1184-y

Klemes, V. (1986). Operational testing of hydrological simulation models. Hydrological Sciences Journal, 31(1), 13-24. Scopus. https://doi.org/10.1080/02626668609491024

Laizé, C. L. R., Acreman, M. C., Schneider, C., Dunbar, M. J., Houghton-Carr, H. A., Flörke, M., \& Hannah, D. M. (2014). Projected flow alteration and ecological risk for pan-european rivers. River Research and Applications, 30(3), 299-314. https://doi.org/10.1002/rra.2645

Lebecherel, L. (2015). Sensibilité des calculs hydrologiques à la densité des réseaux de mesure hydrométrique et pluviométrique [Thèse de doctorat]. Irstea, AgroParisTech.

Lebecherel, Laure, Andréassian, V., \& Perrin, C. (2016). On evaluating the robustness of spatial-proximity-based regionalization methods. Journal of Hydrology, 539, 196-203. http://dx.doi.org/10.1016/j.jhydrol.2016.05.031

Li, L.-J., Zhang, L., Wang, H., Wang, J., Yang, J.-W., Jiang, D.-J., Li, J.-Y., \& Qin, D.Y. (2007). Assessing the impact of climate variability and human activities on streamflow from the Wuding River basin in China. Hydrological Processes, 21(25), 3485-3491. https://doi.org/10.1002/hyp.6485

Li, S., Xiong, L., Dong, L., \& Zhang, J. (2013). Effects of the Three Gorges Reservoir on the hydrological droughts at the downstream Yichang station during 20032011. Hydrological Processes, 27(26), 3981-3993. https://doi.org/10.1002/hyp.9541 
1364 Littlewood, I. G., \& Marsh, T. J. (1996). Re-assessment of the monthly naturalized flow

1365

1366

1367

1368

1369

1370

1371

1372

1373

1374

1375

1376

1377

1378

1379

1380

1381

1382

1383

1384

1385

1386 record for the River Thames at Kingston since 1883, and the implications for the relative severity of historical droughts. River Research and Applications, 12(1), 13-26. https://doi.org/10.1002/(SICI)1099-1646(199601)12:1<13::AIDRRR364>3.0.CO;2-N

Ma, H., Yang, D., Tan, S. K., Gao, B., \& Hu, Q. (2010). Impact of climate variability and human activity on streamflow decrease in the Miyun Reservoir catchment. Journal of Hydrology, 389(3-4), 317-324. https://doi.org/10.1016/j.jhydrol.2010.06.010

Magirl, C. S., Hilldale, R. C., Curran, C. A., Duda, J. J., Straub, T. D., Domanski, M., \& Foreman, J. R. (2014). Large-scale dam removal on the Elwha River, Washington, USA: Fluvial sediment load. Geomorphology, 246, 669-686. https://doi.org/10.1016/j.geomorph.2014.12.032

Maheshwari, B. L., Walker, K. F., \& McMahon, T. A. (1995). Effects of regulation on the flow regime of the River Murray, Australia. River Research and Applications, 10(1), 15-38. https://doi.org/10.1002/rrr.3450100103

Margat, J., \& Andréassian, V. (2008). L'eau (Le Cavalier Bleu).

Maurel, F., Lepelletier, T., Moreau, J., Noeuveglise, C., \& Lancelot, B. (2008). Prospective assessment in water consumption-resources in Seine-Normandie basin. Houille Blanche, 5, 45-52. https://doi.org/10.1051/lhb:2008053

McCully, P. (2001). A new order for river and society: the world commission on dams, and beyond. In Silenced rivers. The ecology and politics of large dams. (pp. i1xxii). Zed books. 
1387

1388

1389

1390

1391

1392

1393

1394

1395

1396

1397

1398

1399

1400

1401

1402

1403

1404

1405

1406

1407

1408

1409

McMillan, H., Krueger, T., \& Freer, J. (2012). Benchmarking observational uncertainties for hydrology: rainfall, river discharge and water quality. Hydrological Processes, 26(26), 4078-4111. https://doi.org/10.1002/hyp.9384

Montanari, A., Young, G., Savenije, H. H. G., Hughes, D., Wagener, T., Ren, L. L., Koutsoyiannis, D., Cudennec, C., Toth, E., Grimaldi, S., Blöschl, G., Sivapalan, M., Beven, K., Gupta, H., Hipsey, M., Schaefli, B., Arheimer, B., Boegh, E., Schymanski, S. J., ... Belyaev, V. (2013). "Panta Rhei-Everything Flows": Change in hydrology and society_-The IAHS Scientific Decade 2013-2022. Hydrological Sciences Journal, 58(6), 1256-1275. https://doi.org/10.1080/02626667.2013.809088

Morin, G., Fortin, J. P., \& Charbonneau, R. (1975). Utilisation du modèle hydrophysiographique CEQUEAU pour l'exploitation des réservoirs artificiels. IAHS Publication, 115, 176-184.

MPO. (2013). Cadre d'évalutaion des exigences relatives au débit écologique nécessaire pour soutenir les pêches au Canada. Secr. can. de consult. sci. du MPO, Avis. sci. 2013/017. (p. 18).

Mwedzi, T., Katiyo, L., Mugabe, F. T., Bere, T., Bangira, C., Mangadze, T., \& Kupika, O. L. (2016). A spatial assessment of stream-flow characteristics and hydrologic alterations, post dam construction in the Manyame catchment, Zimbabwe. Water SA, 42(2), 194-202. https://doi.org/10.4314/wsa.v42i2.03

Naik, P. K., \& Jay, D. A. (2005). Estimation of Columbia River virgin flow: 1879 to 1928. Hydrological Processes, 19(9), 1807-1824.

https://doi.org/10.1002/hyp.5636 
1410 Nobert, J., \& Jeremiah, J. (2012). Hydrological Response of Watershed Systems to

1411

1412

1413

1414

1415

1416

1417

1418

1419

1420

1421

1422

1423

1424

1425

1426

1427

1428

1429

1430

1431

1432

1433

1434 Land Use/Cover Change. A Case of Wami River Basin. The Open Hydrology Journal, 6, 78-87. https://doi.org/10.2174/1874378101206010078

NSW Scientific Committee. (2002). Alteration to the natural flow regimes of rivers, streams, floodplains \& wetlands - key threatening process listing. NSW Scientific Committee - final determination.

http://www.environment.nsw.gov.au/threatenedspecies/AlterationNaturalFlowK TPListing.htm

Oudin, L., Michel, C., \& Anctil, F. (2005). Which potential evapotranspiration input for a lumped rainfall-runoff model? Part 1 - Can rainfall-runoff models effectively handle detailed potential evapotranspiration inputs? Journal of Hydrology, 303(1-4), 275-289. https://doi.org/10.1016/j.jhydrol.2004.08.025

Oudin, L., Perrin, C., Mathevet, T., Andréassian, V., \& Michel, C. (2006). Impact of biased and randomly corrupted inputs on the efficiency and the parameters of watershed models. Journal of Hydrology, 320(1-2), 62-83. Scopus. https://doi.org/10.1016/j.jhydrol.2005.07.016

Pacheco-Guerrero, A., Goodrich, D. C., Gonzalez-Trinidad, J., Junez-Ferreira, H. E., \& Bautista-Capetillo, C. F. (2017). Flooding in ephemeral streams: incorporating transmission losses. Journal of Maps, 13(2), 350-357. https://doi.org/10.1080/17445647.2017.1305303

Pagano, T. C., \& Sorooshian, S. (2005). 173: Global Water Cycle (Fundamental, Theory, Mechanisms). In Encyclopedia of Hydrological Sciences (WileyBlackwell, Vol. 5, pp. 2697-2711). Malcolm G. Anderson.

Page, K., Read, A., Frazier, P., \& Mount, N. (2005). The effect of altered flow regime on the frequency and duration of bankfull discharge: Murrumbidgee River, 
1435

1436

1437

1438

1439

1440

1441

1442

1443

1444

1445

1446

1447

1448

1449

1450

1451

1452

1453

1454

1455

1456

1457

1458

1459

Australia. River Research and Applications, 21(5), 567-578. https://doi.org/10.1002/rra.828

Pechlivanidis, I. G., Jackson, B. M., McIntyre, N. R., \& Wheater, H. S. (2011).

Catchment scale hydrological modelling: a review of model types, calibration approaches and uncertainty analysis methods in the context of recent developments in technology and applications. Global NEST Journal, 13(3), $193-214$.

Peters, D. L., \& Prowse, T. D. (2001). Regulation effects on the lower Peace River, Canada. Hydrological Processes, 15(16), 3181-3194. https://doi.org/10.1002/hyp.321

Peters, D. L., Prowse, T. D., Pietroniro, A., \& Leconte, R. (2006). Flood hydrology of the Peace-Athabasca Delta, northern Canada. Hydrological Processes, 20(19), 4073-4096. https://doi.org/10.1002/hyp.6420

Poff, N. L., Allan, J. D., Bain, M. B., Karr, J. R., Prestegaard, K. L., Richter, B. D., Sparks, R. E., \& Stromberg, J. C. (1997). The natural flow regime: A paradigm for river conservation and restoration. BioScience, 47(11), 769-784. Scopus. https://doi.org/10.2307/1313099

Rahman, S., \& Bowling, L. (2018). Streamflow Impacts of Management and Environmental Change in the Upper Wabash River Basin. Journal of Hydrologic Engineering, 24(3), 05018034. https://doi.org/10.1061/(ASCE)HE.19435584.0001750

Refsgaard, J. C., van der Sluijs, J. P., Højberg, A. L., \& Vanrolleghem, P. A. (2007). Uncertainty in the environmental modelling process - A framework and guidance. Environmental Modelling \& Software, 22(11), 1543-1556. https://doi.org/10.1016/j.envsoft.2007.02.004 
1460 Richter, B. D., Baumgartner, JV., Powell, J., \& Braun, D. (1996). A Method for

1461

1462

1463

1464

1465

1466

1467

1468

1469

1470

1471

1472

1473

1474

1475

1476

1477

1478

1479

1480

1481

1482

1483

1484

Assessing Hydrologic Alteration within Ecosystems. Conservation Biology, 10(4), 1163-1174. https://doi.org/10.1046/j.1523-1739.1996.10041163.x

Risques et Développement, \& Maison régionale de l'Eau. (2012). Etudes d'estimation des volumes prélevables globaux - Sous bassin versant des Usses - Rapport final (in french) (p. 214). Agence de l'Eau Rhône Méditerranée et Corse.

http://www.rhone-mediterranee.eaufrance.fr/docs/gestionquantitative/EEVPG/Usses/EVP_Usses_rapport_phase1a3_dec2012.pdf

Roubicek, A. J. (2010). Does the choice of climate baseline matter in ecological niche modelling? Ecological Modelling, 221(19), 2280-2286. https://doi.org/10.1016/j.ecolmodel.2010.06.021

Ryo, M., Iwasaki, Y., Yoshimura, C., \& Saavedra V, O. C. (2015). Evaluation of spatial pattern of altered flow regimes on a river network using a distributed hydrological model. PLoS ONE, 10(7). https://doi.org/10.1371/journal.pone.0133833

SAFEGE Ingénieurs Conseils. (2011). Etude de détermination des volumes prélevables sur le bassin versant de la Tille - Rapport de Phase 3 (in french) (Version finale (3.2); p. 118). Agence de l'Eau Rhône Méditerranée et Corse. http://www.rhonemediterranee.eaufrance.fr/docs/gestionquantitative/EEVPG/Tille/EVP_Tille_rapport_phase3_dec2011.pdf

Schreiner-McGraw, A. P., \& Vivoni, E. R. (2018). On the Sensitivity of Hillslope Runoff and Channel Transmission Losses in Arid Piedmont Slopes. Water Resources Research, 54(7), 4498-4518. https://doi.org/10.1029/2018WR022842

Shi, P., Ma, X., Hou, Y., Li, Q., Zhang, Z., Qu, S., Chen, C., Cai, T., \& Fang, X. (2013). Effects of Land-Use and Climate Change on Hydrological Processes in the 
1485

1486

1487

1488

1489

1490

1491

1492

1493

1494

1495

1496

1497

1498

1499

1500

1501

1502

1503

1504

1505

1506

1507

1508

Upstream of Huai River, China. Water Resources Management, 27(5), 12631278. https://doi.org/10.1007/s11269-012-0237-4

Shiklomanov, A. I., \& Lammers, R. B. (2009). Record Russian river discharge in 2007 and the limits of analysis. Environmental Research Letters, 4(4), 045015. https://doi.org/10.1088/1748-9326/4/4/045015

Siriwardena, L., Finlayson, B. L., \& McMahon, T. A. (2006). The impact of land use change on catchment hydrology in large catchments: The Comet River, Central Queensland, Australia. Journal of Hydrology, 326(1-4), 199-214. https://doi.org/10.1016/j.jhydrol.2005.10.030

Sivapalan, M., Takeuchi, K., Franks, S. W., Gupta, V. K., Karambiri, H., Lakshmi, V., Liang, X., McDONNELL, J. J., Mendiondo, E. M., O’Connell, P. E., Oki, T., Pomeroy, J. W., Schertzer, D., Uhlenbrook, S., \& Zehe, E. (2003). IAHS Decade on Predictions in Ungauged Basins (PUB), 2003-2012: Shaping an exciting future for the hydrological sciences. Hydrological Sciences Journal, 48(6), 857880. https://doi.org/10.1623/hysj.48.6.857.51421

Slabbert, N. (2007). The potential impact of an inter-basin water transfer on the Modder and Caledon river systems - Chapter 1: An overview of inter-basin transfer schemes and the South African perspectives. [University of the Free State]. http://citeseerx.ist.psu.edu/viewdoc/download?doi=10.1.1.471.5502\&rep=rep1\& type $=$ pdf

Smakhtin, V. Y. (1999). Generation of natural daily flow time-series in regulated rivers using a non-linear spatial interpolation technique. River Research and Applications, 15(4), 311-323. 
1509 Socièté du Canal de Provence, \& ASCONIT Consultants. (2012). Etudes d'estimation

1510

1511

1512

1513

1514

1515

1516

1517

1518

1519

1520

1521

1522

1523

1524

1525

1526

1527

1528

1529

1530

1531

1532

1533 des volumes prélevables globaux - Sous bassin versant de la Berre - Rapport final phase 3 (in french) (p. 73). Agence de l'Eau Rhône Méditerranée et Corse. http://www.rhone-mediterranee.eaufrance.fr/docs/gestionquantitative/EEVPG/berre-dromoise/EVP_berre_rapport-ph3_juillet2012.pdf

SOGREAH. (2012). Etudes de détermination des volumes prélevables - Bassin versant du Sègre -Rapport de phases 1, 2 et 3 (in french) (No. 4331135-v10; p. 116).

Agence de l'Eau Rhône Méditerranée et Corse. http://www.rhone-

mediterranee.eaufrance.fr/docs/gestion-

quantitative/EEVPG/Segre/EVP_Segre_rapport_phase1a3_nov2012.pdf

SOGREAH, anteagroup, \& Pierre Paris Consultant. (2011). Etude de détermination des volumes maximum prélevables - Phase 3: Impact des prélèvements et quantification des ressources existantes (in french). (No. 1741452; p. 116).

Agence de 1'Eau Rhône Méditerranée et Corse. http://www.rhonemediterranee.eaufrance.fr/docs/gestionquantitative/EEVPG/Ouche/EVP_Ouche_rapport_phase3_juin2011.pdf

SOGREAH Consultants, \& EPTEAU. (2012). Etudes d'estimation des volumes prélevables globaux - Sous bassin versant de La Basse Vallée de l'Ain - Rapport de phase 3 (in french) (p. 115). Agence de l'Eau Rhône Méditerranée et Corse. http://www.rhone-mediterranee.eaufrance.fr/docs/gestionquantitative/EEVPG/bv_Ain/EVP_BVA_rapport_phase3_juin2012.pdf

Stahl, K., Hisdal, H., Hannaford, J., Tallaksen, L. M., van Lanen, H. A. J., Sauquet, E., Demuth, S., Fendekova, M., \& Jodar, J. (2010). Streamflow trends in Europe: evidence from a dataset of near-natural catchments. Hydrology and Earth System Sciences, 14, 2367-2382. https://doi.org/10.5194/hess-14-2367-2010 
1534 Stednick, J. D. (1996). Monitoring the effects of timber harvest on annual water yield.

1535

1536

1537

1538

1539

1540

1541

1542

1543

1544

1545

1546

1547

1548

1549

1550

1551

1552

1553

1554

1555

1556 Journal of Hydrology, 176(1-4), 79-95. https://doi.org/10.1016/00221694(95)02780-7

Steffen, W., Broadgate, W., Deutsch, L., Gaffney, O., \& Ludwig, C. (2015). The trajectory of the Anthropocene: The Great Acceleration. The Anthropocene Review, 2(1), 81-98. https://doi.org/10.1177/2053019614564785

Steffen, W., Grinevald, J., Crutzen, P., \& McNeill, J. (2011). The Anthropocene: conceptual and historical perspectives. Philosophical Transactions of the Royal Society A: Mathematical, Physical and Engineering Sciences, 369(1938), 842867. https://doi.org/10.1098/rsta.2010.0327

Stoddard, J. L., Larsen, D. P., Hawkins, C. P., Johnson, R. K., \& Norris, R. H. (2006). Setting expectations for the ecological condition of streams: the concept of reference condition. Ecological Applications, 16(4), 1267-1276. https://doi.org/10.1890/1051-0761(2006)016[1267:SEFTEC]2.0.CO;2

Tardieu, H. (2008). Water scarcity, new challenges for the operational management of " sustainable infrastructures ". La Houille Blanche, 6, 85-92. https://doi.org/10.1051/lhb:2008076

Theis, C. V. (1941). The effect of a weel on the flow of a nearby stream. Eos, Transactions American Geophysical Union, 22(3), 734-738. https://doi.org/10.1029/TR022i003p00734

Tongal, H., Demirel, M. C., \& Moradkhani, H. (2017). Analysis of dam-induced cyclic patterns on river flow dynamics. Hydrological Sciences Journal, 62(4), 626641. https://doi.org/DOI: 10.1080/02626667.2016.1252841 
1557 USGS, \& National Water-Use Science Project. (2019). Water-Use Terminology.

1558

1559

1560

1561

1562

1563

1564

1565

1566

1567

1568

1569

1570

1571

1572

1573

1574

1575

1576

1577

1578

1579

1580 https://www.usgs.gov/mission-areas/water-resources/science/water-useterminology?qt-science_center_objects $=0 \# q t-$ science_center_objects

Vidal, J. P. (2019). Écrire l'hydrologie de l'Anthropocène [Mémoire d'Habilitation à diriger des recherches]. Université Grenoble Alpes, Ecole Doctorale Terre, Univers, Environnement.

Villocel, A. (2002). Le système Neste Développement d'une approche citoyenne de la ressource en eau (The Neste system-Development of a citizen-based approach of water resources management). La Houille Blanche, 4-5(78-82).

Vörösmarty, C. J., \& Sahagian, D. (2000). Anthropogenic Disturbance of the Terrestrial Water Cycle. BioScience, 50(9), 753. https://doi.org/10.1641/00063568(2000)050[0753:ADOTTW]2.0.CO;2

Wallace, R. B., \& Pavvloski, J. T. (1988). Assessing impacts of irrigation on streamflow. Journal of Irrigation and Drainage Engineering, 114(2), 211-225. https://doi.org/10.1061/(ASCE)0733-9437(1988)114:2(211)

Wang, G., Xia, J., \& Chen, J. (2009). Quantification of effects of climate variations and human activities on runoff by a monthly water balance model: A case study of the Chaobai River basin in northern China: Climate variations and human activites. Water Resources Research, 45(7). https://doi.org/10.1029/2007WR006768

Wang, J., Hong, Y., Gourley, J., Adhikari, P., Li, L., \& Su, F. (2010). Quantitative assessment of climate change and human impacts on long-term hydrologic response: a case study in a sub-basin of the Yellow River, China. International Journal of Climatology, 30(14), 2130-2137. https://doi.org/10.1002/joc.2023 
1581 Wang, W., Shao, Q., Yang, T., Peng, S., Xing, W., Sun, F., \& Luo, Y. (2013).

1582

1583

1584

1585

1586

1587

1588

1589

1590

1591

1592

1593

1594

1595

1596

1597

1598

1599

1600

1601

1602

1603

1604

1605

Quantitative assessment of the impact of climate variability and human activities on runoff changes: a case study in four catchments of the Haihe River basin, China. Hydrological Processes, 27(8), 1158-1174. https://doi.org/10.1002/hyp.9299

WaterNSW. (2015). Glossary of water terms. WaterNSW. http://www.waternsw.com.au/customer-service/iwas/glossary

Weingartner, R., \& Aschwanden, H. (1994). Quantification des débits des cours d'eau des Alpes suisses et des influences anthropiques qui les affectent. Revue de géographie alpine, 82(2), 45-57. https://doi.org/10.3406/rga.1994.3749

Wen, L. (2009). Reconstruction natural flow in a regulated system, the Murrumbidgee River, Australia, using time series analysis. Journal of Hydrology, 364(3-4), 216-226. Scopus. https://doi.org/10.1016/j.jhydrol.2008.10.023

Whitfield, P. H., Burn, D. H., Hannaford, J., Higgins, H., Hodgkins, G. A., Marsh, T., \& Looser, U. (2012). Reference hydrologic networks I. The status and potential future directions of national reference hydrologic networks for detecting trends. Hydrological Sciences Journal, 57(8), 1562-1579. https://doi.org/10.1080/02626667.2012.728706

Winton, R. S., Calamita, E., \& Wehrli, B. (2019). Reviews and syntheses: Dams, water quality and tropical reservoir stratification. Biogeosciences, 16, 1657-1671. https://doi.org/10.5194/bg-16-1657-2019

WMO. (2012). Glossaire international d'hydrologie - International glossary of hydrology. (Vol. 385). World Meteorological Organization.

Wu, F. C., Chang, C. F., \& Shiau, J. T. (2015). Assessment of flow regime alterations over a spectrum of temporal scales using wavelet-based approaches. Water 
1606

1607

1608

1609

1610

1611

1612

1613

1614

1615

1616

1617

1618

1619

1620

1621

1622

1623

1624

1625

1626

1627

1628

1629

1630

Resources Research, 51(5), 3317-3338. Scopus.

https://doi.org/10.1002/2014WR016595

Wurbs, R. A. (2006). Methods for developing naturalized monthly flows at gaged and ungaged sites. Journal of Hydrologic Engineering, 11(1), 55-64. Scopus. https://doi.org/10.1061/(ASCE)1084-0699(2006)11:1(55)

WWAP. (2009). The United Nations World Water Development Report 3: Water in a changing world (p. 429). Paris: UNESCO \& London: Earthscan.

Wyrick, J. R., Rischman, B. A., Burke, C. A., McGee, C., \& Williams, C. (2009a). Using hydraulic modeling to address social impacts of small dam removals in southern New Jersey. Journal of Environmental Management, 90, S270-S278. https://doi.org/10.1016/j.jenvman.2008.07.027

Wyrick, J. R., Rischman, B. A., Burke, C. A., McGee, C., \& Williams, C. (2009b). Using hydraulic modeling to address social impacts of small dam removals in southern New Jersey. Journal of Environmental Management, 90, S270-S278. https://doi.org/10.1016/j.jenvman.2008.07.027

Ye, B., Yang, D., \& Kane, D. L. (2003). Changes in Lena River streamflow hydrology: Human impacts versus natural variations. Water Resources Research, 39(7). https://doi.org/10.1029/2003WR001991

Yin, J., He, F., Xiong, Y. J., \& Qiu, G. Y. (2017). Effects of land use/land cover and climate changes on surface runoff in a semi-humid and semi-arid transition zone in northwest China. Hydrology and Earth System Sciences, 21(1), 183-196. https://doi.org/10.5194/hess-21-183-2017

Young, A. R., Grew, R., \& Holmes, M. G. R. (2003). Low Flows 2000: a national water resources assessment and decision support tool. Water Science and Technology, 48(10), 119-126. https://doi.org/10.2166/wst.2003.0554 
1631 Yuan, X., Zhang, M., Wang, L., \& Zhou, T. (2017). Understanding and seasonal 1632 forecasting of hydrological drought in the Anthropocene. Hydrology and Earth System Sciences, 21(11), 5477-5492. https://doi.org/10.5194/hess-21-5477-2017

1634 Zhan, C., Niu, C., Song, X., \& Xu, C. (2013). The impacts of climate variability and 1635 human activities on streamflow in Bai River basin, northern China. Hydrology 1636 Research, 44(5), 875. https://doi.org/10.2166/nh.2012.146

1637 Zhang, Ling, Nan, Z., Xu, Y., \& Li, S. (2016). Hydrological Impacts of Land Use 1638 Change and Climate Variability in the Headwater Region of the Heihe River 1639 Basin, Northwest China. PLOS ONE, 11(6), e0158394.

1640 https://doi.org/10.1371/journal.pone.0158394

1641 Zhang, Lu, Cheng, L., Chiew, F., \& Fu, B. (2018). Understanding the impacts of 1642 climate and landuse change on water yield. Current Opinion in Environmental 1643 Sustainability, 33, 167-174. https://doi.org/10.1016/j.cosust.2018.04.017 

4 5 6

7

8

10 
1647 [Table 7 here]

1648

1649

10

11

12

13

14

15

16

17

18

19

20

21

22

23

24

25

26

27

28

29

30

31

32

33

34

35

36

37

38

39

40

41

42

43

44

45

46

47

48

49

50

51

52

53

54

55

56

57

58

59

60 
1651 Table 1. Definitions of "natural streamflow" and "natural regime" found in the 1652 literature.

1653 Table 2. Synthesis of studies applying Water Balance methods.

1654 Table 3. Synthesis of studies applying Reconstitution methods.

1655 Table 4. Synthesis of studies applying Extension methods.

1656 Table 5. Synthesis of models used in studies applying Routing modelling methods.

1657 Table 6. Synthesis of input data and tools used by each of the naturalization methods.

1658 Table 7. Synthesis of withdrawable water volume studies. WB corresponds to the Water

1659 Balance method, $\mathrm{R}$ to the Reconstitution method, $\mathrm{E}$ to the Extension method and $\mathrm{N}$ to 1660 the Neighbourhood method.

1661 Figure 1. Schematic representation of the impacts of human activities and the water 1662 cycle components they may directly impact (derived from Botai et_ al...201015).

1663 Figure 2. A catchment impacted by human activities: gauging stations A1 and B1 are 1664 uninfluenced, gauging stations A2, B2 and $\mathrm{C}$ are candidates for naturalization 1665 procedures (Source: INRAE).

1666 Figure 3. Diagram of the three periods distinguished in naturalization.

1667 Figure 4. Hydrograph at logarithmic scale of the daily observed streamflow of the Aube 1668 River at Arcis-sur-Aube (France, $3560 \mathrm{~km}^{2}$ ). The red line corresponds to the upstream 1669 dam's commissioning in 1990.

1670 Figure 5. Diagram of the choice of naturalization according to the available data.

1671 Figure 6. Naturalization methods applied in the studies reviewed.

1672 Figure 7. Illustration of the two application steps of the Reconstitution method.

1673 Figure 8. Illustration of the two application steps of the Extension method.

1674 Figure 9. Map of the withdrawable water volumes in the catchments studied (Rhône1675 Mediterranean district). 


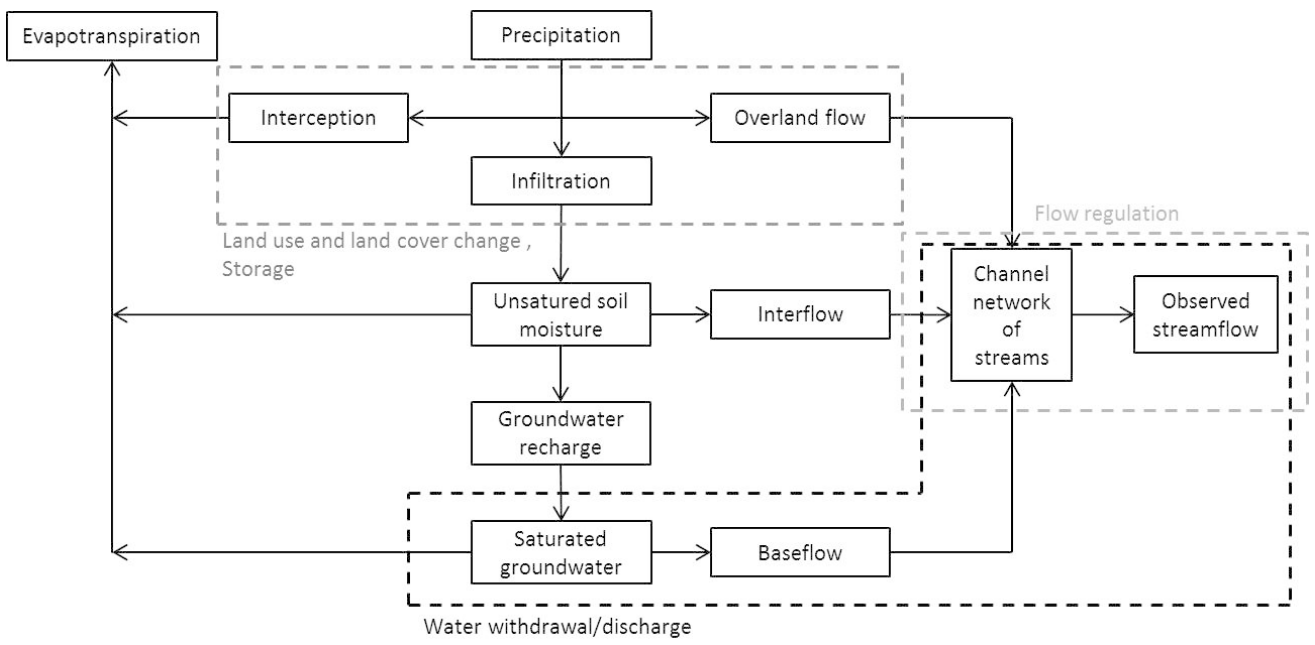

Schematic representation of the impacts of human activities and the water cycle components they may directly impact (derived from Botai et al., 2015)

$218 \times 108 \mathrm{~mm}(150 \times 150 \mathrm{DPI})$ 


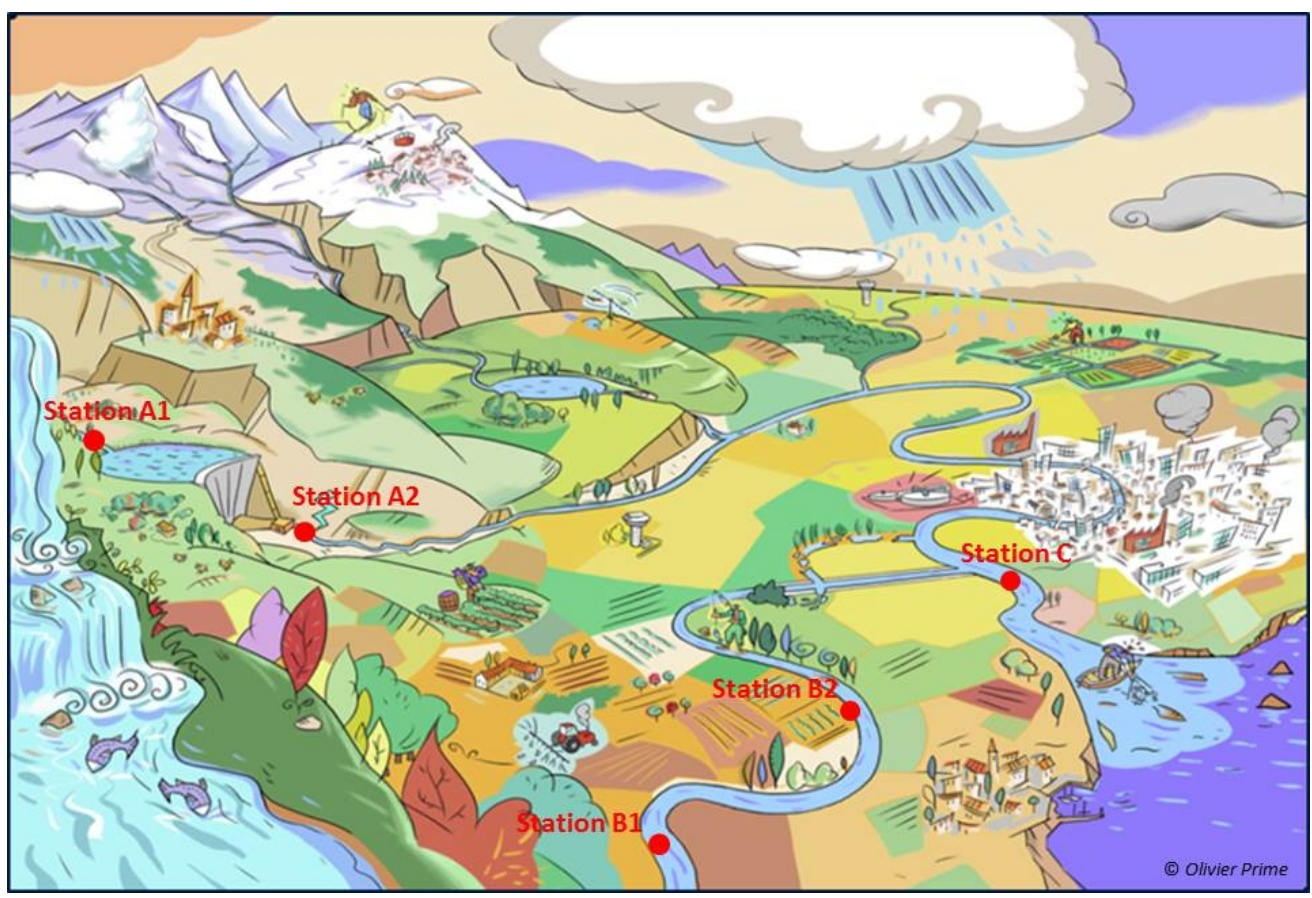

A catchment impacted by human activities: gauging stations $A 1$ and $B 1$ are uninfluenced, gauging stations $\mathrm{A} 2, \mathrm{~B} 2$ and $\mathrm{C}$ are candidates for naturalization procedures (Source: INRAE)

$162 \times 110 \mathrm{~mm}(150 \times 150 \mathrm{DPI})$ 


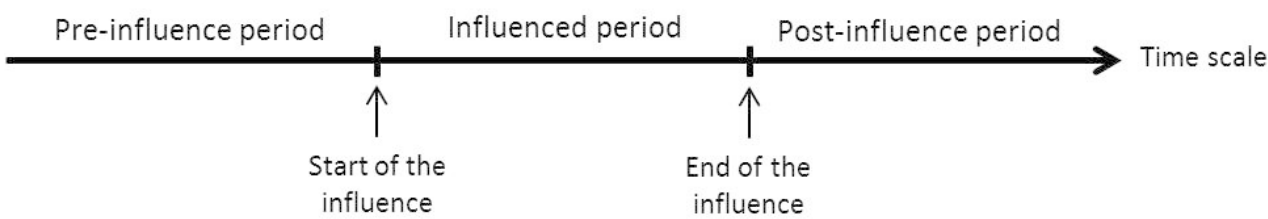

Diagram of the three periods distinguished in naturalization.

$168 \times 31 \mathrm{~mm}(150 \times 150 \mathrm{DPI})$ 


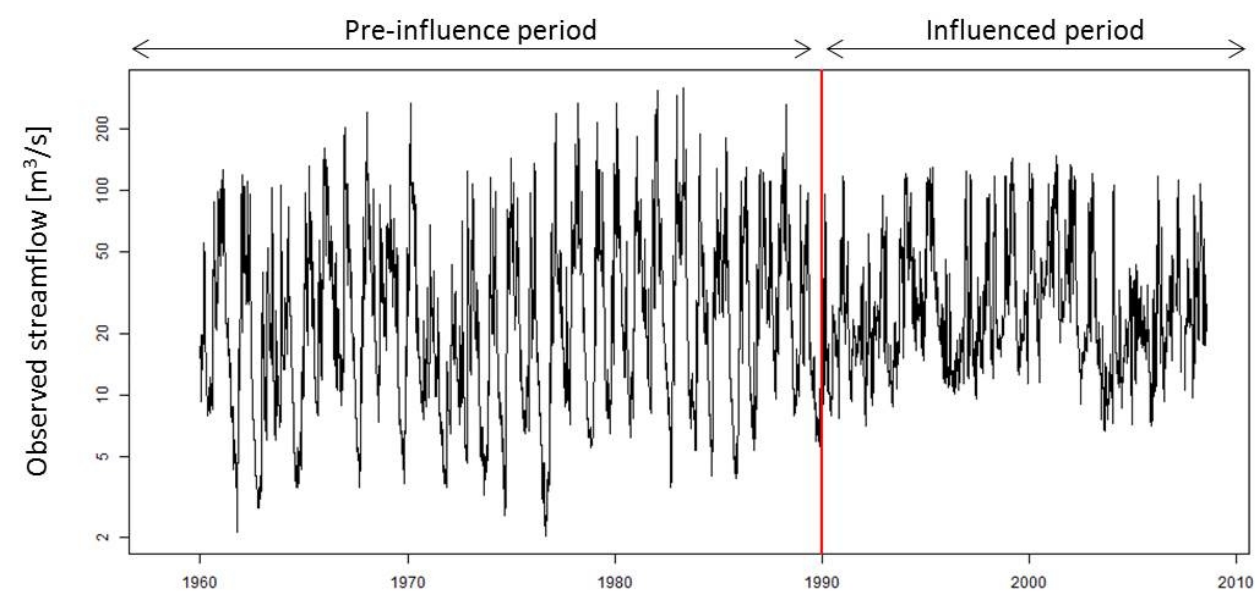

Hydrograph at logarithmic scale of the daily observed streamflow of the Aube River at Arcis-sur-Aube (France, $3560 \mathrm{~km}^{2}$ ). The red line corresponds to the upstream dam's commissioning in 1990. $180 \times 88 \mathrm{~mm}(150 \times 150 \mathrm{DPI})$ 


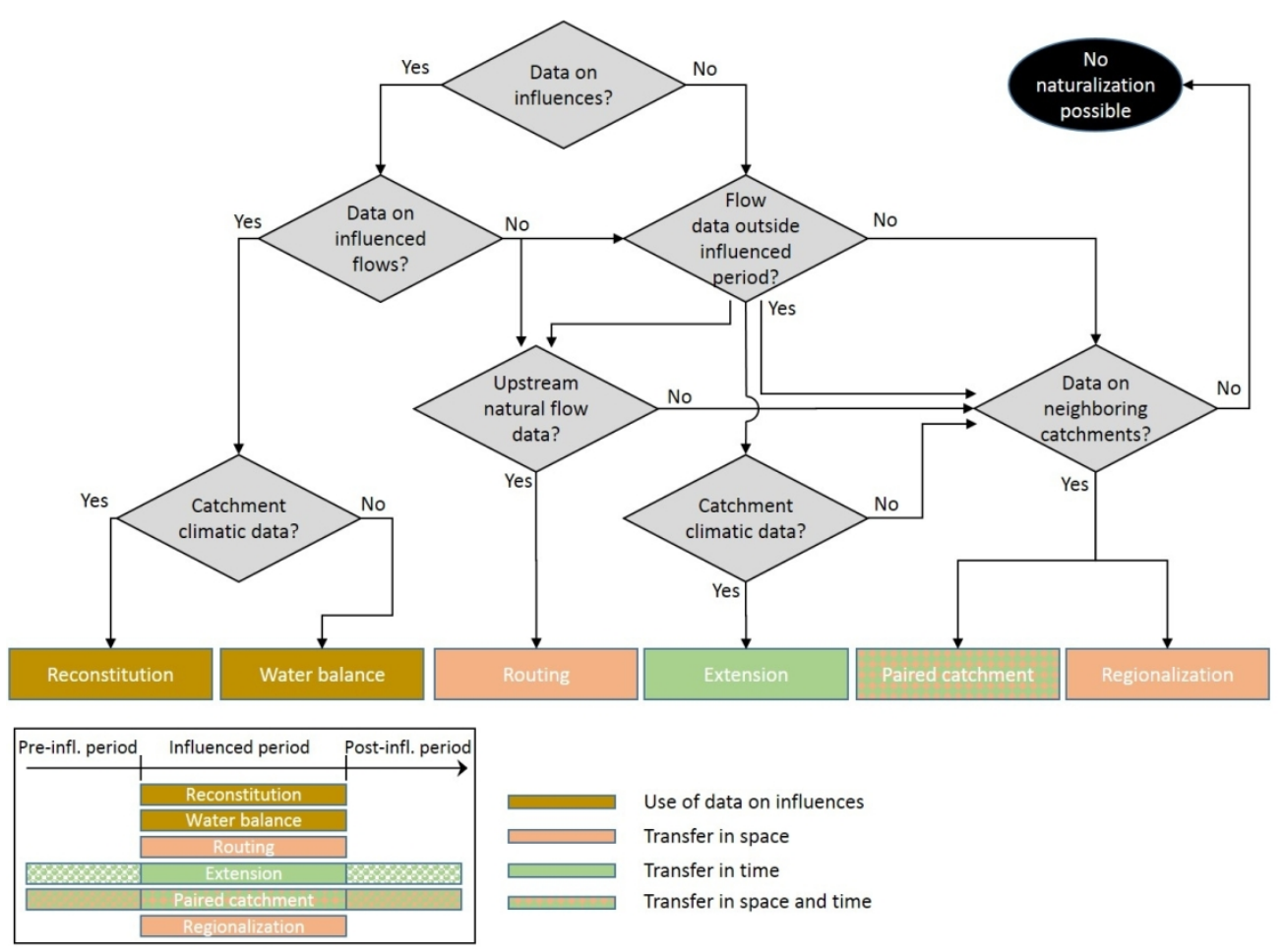

Diagram of the choice of naturalization according to the available data.

$252 \times 183 \mathrm{~mm}(150 \times 150 \mathrm{DPI})$ 


\section{Paired fatchment}

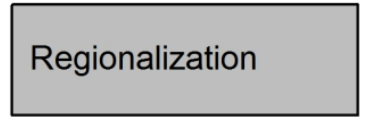

\section{Routing}
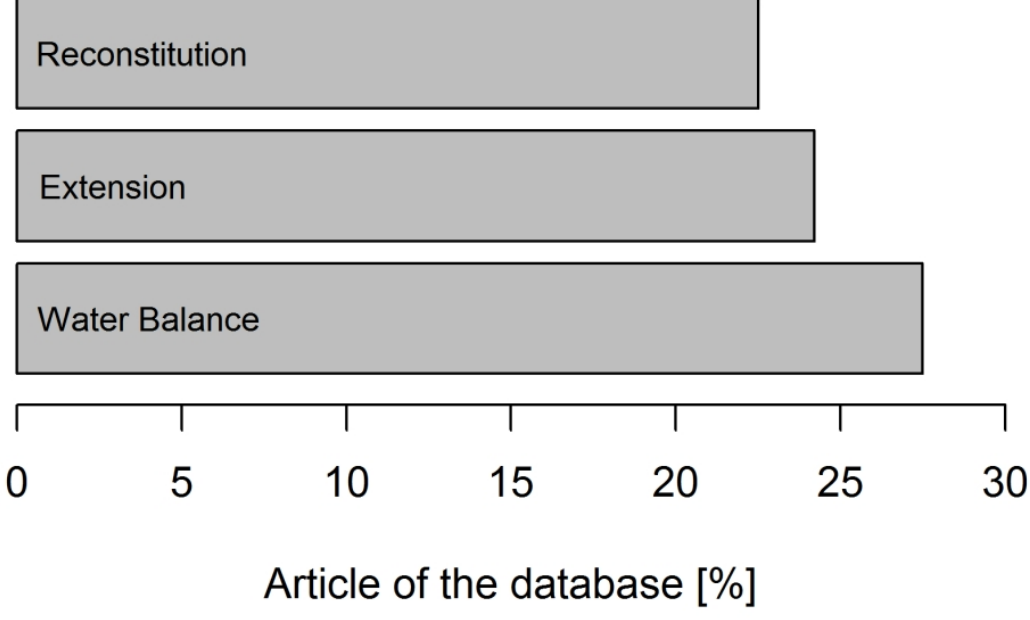

Naturalization methods applied in the studies reviewed. 


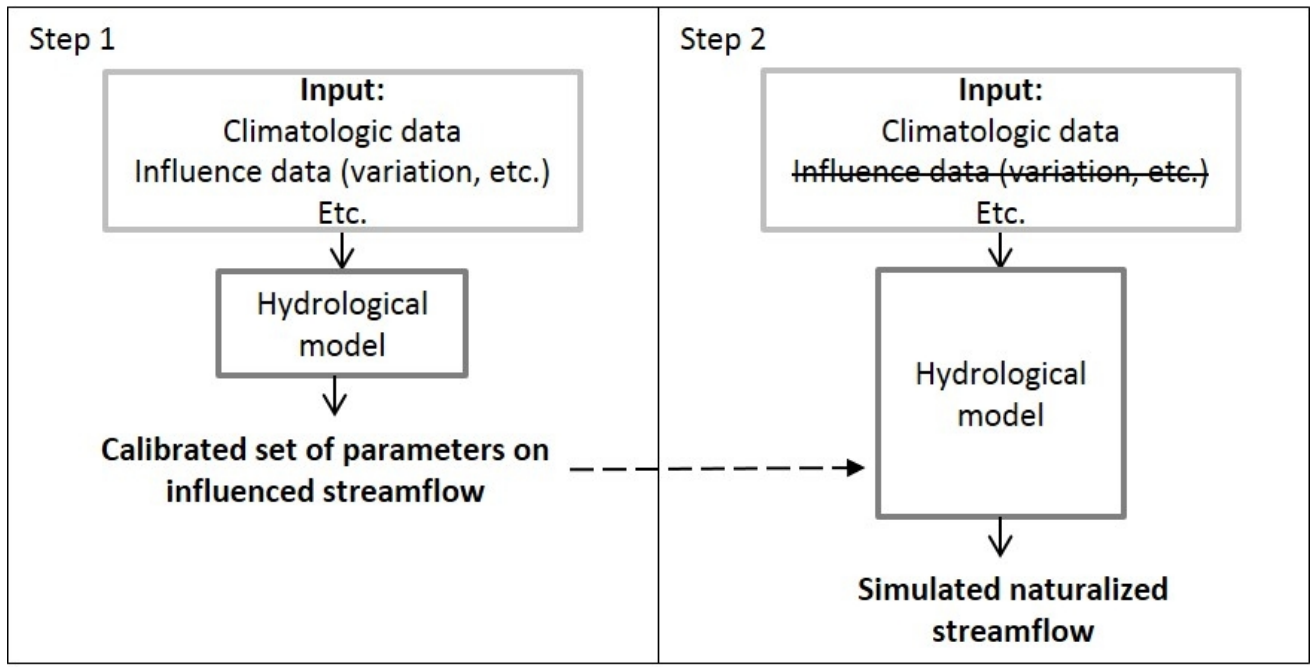

Illustration of the two application steps of the Reconstitution method.

$$
148 \times 76 \mathrm{~mm}(150 \times 150 \mathrm{DPI})
$$




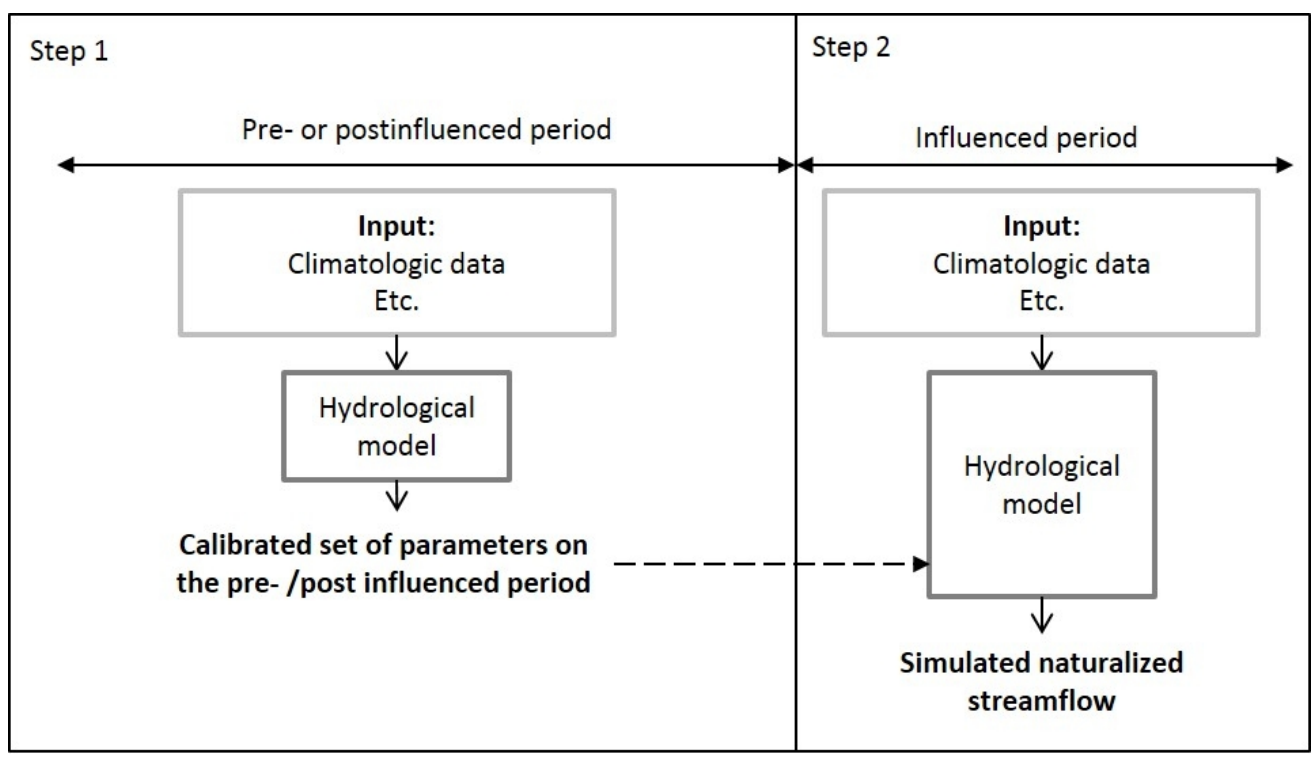

Illustration of the two application steps of the Extension method.

$162 \times 92 \mathrm{~mm}(150 \times 150 \mathrm{DPI})$ 


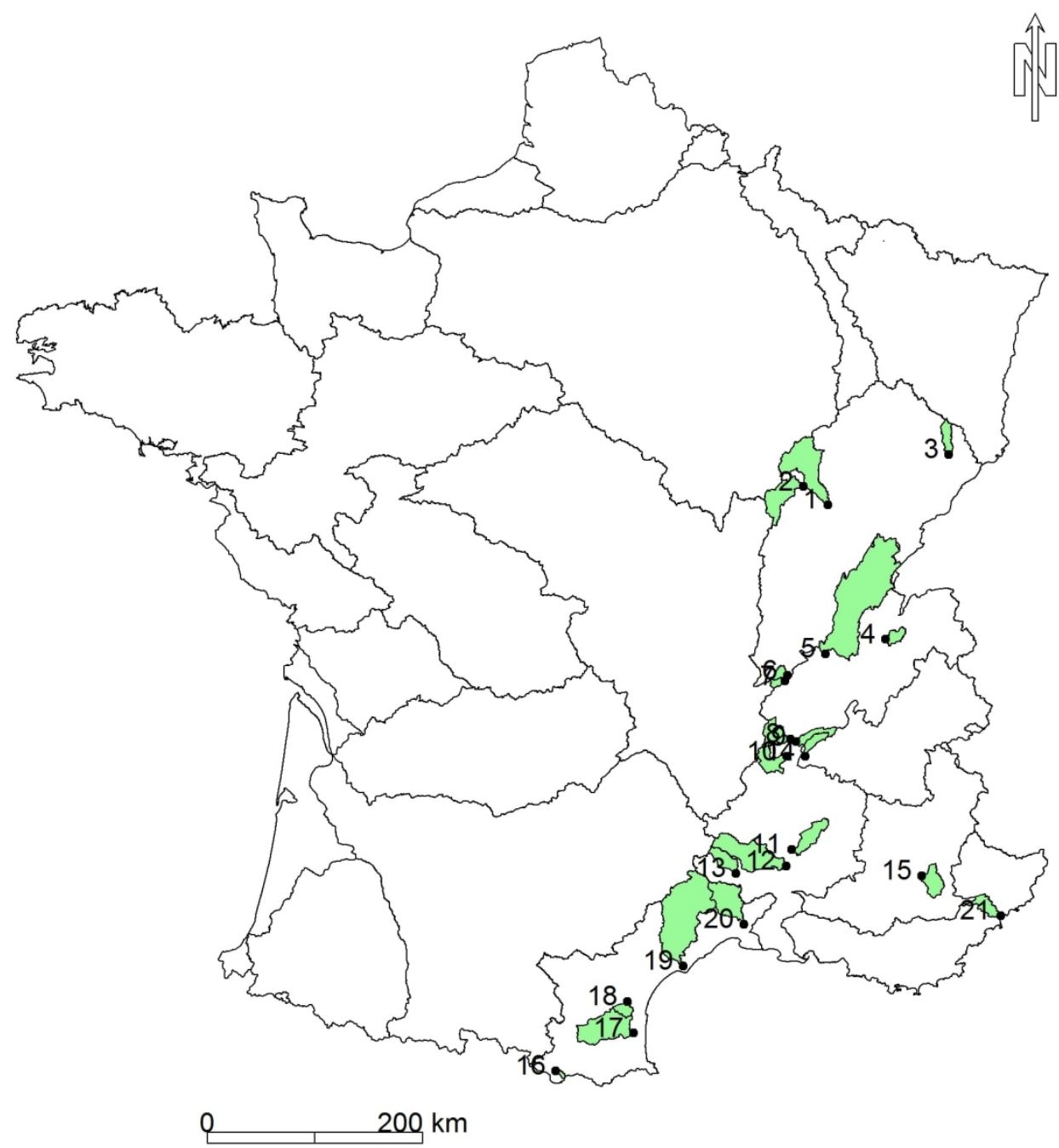

Map of the withdrawable water volumes in the catchments studied (Rhône-Mediterranean district). $638 \times 718 m m(72 \times 72$ DPI $)$ 


\begin{tabular}{|l|l|}
\hline Source & Definition \\
\hline $\begin{array}{l}\text { New South Wales Scientific } \\
\text { Committee in Australia, 2002 }\end{array}$ & $\begin{array}{l}\text { (D1) Natural flow regimes are determined by the climate, run-off, } \\
\text { catchment size and geomorphology without the impacts of dams, } \\
\text { weirs, extraction and river management (NSW Scientific Committee, } \\
\text { 2002). }\end{array}$ \\
\hline $\begin{array}{l}\text { Environmental Protection } \\
\text { Agency in the USA, 2015 }\end{array}$ & $\begin{array}{l}\text { (D2) A stream's natural flow regime is a function of the climate and } \\
\text { physical properties of its unique upstream drainage area (Novak et } \\
\text { al., 2015). }\end{array}$ \\
\hline $\begin{array}{l}\text { Canadian Science Advisory } \\
\text { Secretariat, 2013 }\end{array}$ & $\begin{array}{l}\text { (D3) A “natural flow regime" can be defined as a flow regime that is } \\
\text { only affected by the variability in hydrological inputs and outputs } \\
\text { (precipitation, evaporation) and natural water storage (such as } \\
\text { groundwater) and for which the response in terms of amplitude, } \\
\text { timing, duration and frequency of events is unaltered by human } \\
\text { impacts (DFO, 2013). }\end{array}$ \\
\hline $\begin{array}{l}\text { World Meteorological } \\
\text { Organization, 2012 }\end{array}$ & $\begin{array}{l}\text { (D4) Natural flow corresponds to flow in a stream that would occur } \\
\text { under natural conditions (WMO, 2012). }\end{array}$ \\
\hline
\end{tabular}




\begin{tabular}{|c|c|c|c|c|c|c|}
\hline Authors & Basins & $\begin{array}{l}\text { Size of the } \\
\text { catchments }\end{array}$ & Influence & Time step & Period & Length[year] \\
\hline Irwin et al., 1975 & Venison Creek, Canada & 90 & $\begin{array}{l}\text { Irrigation } \\
\text { abstraction }\end{array}$ & Daily & $\begin{array}{c}\text { July and } \\
\text { August from } \\
1967 \text { to } 1969 \\
\end{array}$ & 0.3 \\
\hline $\begin{array}{l}\text { Wallace et Pawloski, } \\
1988\end{array}$ & $\begin{array}{l}\text { Small stream in central } \\
\text { Michigan }\end{array}$ & 78 & $\begin{array}{l}\text { Irrigation } \\
\text { abstraction }\end{array}$ & Monthly & $\begin{array}{l}\text { From june to } \\
\text { august } 1983\end{array}$ & 0.3 \\
\hline $\begin{array}{l}\text { Littlewood et Marsh, } \\
1996\end{array}$ & $\begin{array}{l}\text { Thanes basin to } \\
\text { Kingston, United } \\
\text { Kingdom }\end{array}$ & 9,950 & $\begin{array}{l}\text { Reservoirs and } \\
\text { abstrasction }\end{array}$ & Monthly & 1883-1992 & 99 \\
\hline Assani et al., 1999 & $\begin{array}{l}\text { La Wache river, } \\
\text { Belgium }\end{array}$ & 118 & Two dams & Daily & $1930-1995$ & 65 \\
\hline Peters et Prowse,2001 & $\begin{array}{l}\text { Lower Peace River, } \\
\text { Canada }\end{array}$ & 293,000 & $\begin{array}{l}\text { Hydroelectric } \\
\text { dam }\end{array}$ & Daily & $1972-1996$ & 24 \\
\hline Wurbs, 2006 & $\begin{array}{l}23 \text { basins in Texas, } \\
\text { USA }\end{array}$ & $\begin{array}{c}648 \text { to } \\
685000 \\
\end{array}$ & & Monthly & & \\
\hline Page et al., 2005 & $\begin{array}{l}\text { Murrumbidgee river, } \\
\text { Murray-Darling river } \\
\text { system, Australia }\end{array}$ & 84,000 & $\begin{array}{l}26 \text { dams, weir, } \\
\text { and irrigation } \\
\text { canals }\end{array}$ & Daily & $1970-1998$ & 28 \\
\hline Jiongxin, 2005 & $\begin{array}{l}\text { Lijin station (outlet of } \\
\text { the river), Yellow } \\
\text { river, China }\end{array}$ & & Diversions & Annual & 1952-1996 & 44 \\
\hline Naik et Jay, 2005 & $\begin{array}{l}\text { Columbia river at the } \\
\text { Dalles }\end{array}$ & 660,480 & $\begin{array}{l}\text { Irrigation } \\
\text { abstraction and } \\
\text { dam }\end{array}$ & Daily & $1879-1928$ & 49 \\
\hline Agosta, 2007 & $\begin{array}{l}\text { Ariege river at Foix, } \\
\text { Garonne, France }\end{array}$ & 1,360 & $\begin{array}{l}\text { Hydroelectric } \\
\text { dams }\end{array}$ & Daily & $1990-2004$ & 14 \\
\hline Maurel et al., 2008 & Seine basins, France & 78,000 & $\begin{array}{l}\text { Industrial, } \\
\text { agricultural } \\
\text { and drinking } \\
\text { water } \\
\text { abstraction } \\
\end{array}$ & Daily & $1975-2004$ & 29 \\
\hline Kim et Wurbs, 2011 & Brazos river basin & 115,565 & $\begin{array}{l}\text { Dam and } \\
\text { diversions }\end{array}$ & Monthly & $1998-2007$ & 9 \\
\hline $\begin{array}{l}\text { Fantin-Cruz et al., } \\
2015\end{array}$ & Correntes river, Brazil & 3,898 & $\begin{array}{l}\text { Hydroelectric } \\
\text { dam }\end{array}$ & Daily & $2005-2012$ & 7 \\
\hline Tongal et al., 2016 & $\begin{array}{l}\text { South Fork Flathead } \\
\text { river }\end{array}$ & 4,248 & Dam & Daily & $1953-2000$ & 47 \\
\hline Davtalab et al., 2017 & Karkheh river, Iran & 50,000 & $\begin{array}{l}\text { Withdrawal for } \\
\text { irrigation and } \\
\text { canals }\end{array}$ & Daily & P & \\
\hline Gu et al., 2017 & Poyang Lake, China & 162,200 & 14 reservoirs & & $1961-2013$ & 52 \\
\hline Yuan et al., 2017 & Yellow river, China & 752,000 & $\begin{array}{l}\text { Irrigation, } \\
\text { diversion, } \\
\text { reservoirs, } \\
\text { withdrawal for } \\
\text { industry and } \\
\text { civil sectors }\end{array}$ & Monthly & $1961-2010$ & 49 \\
\hline
\end{tabular}




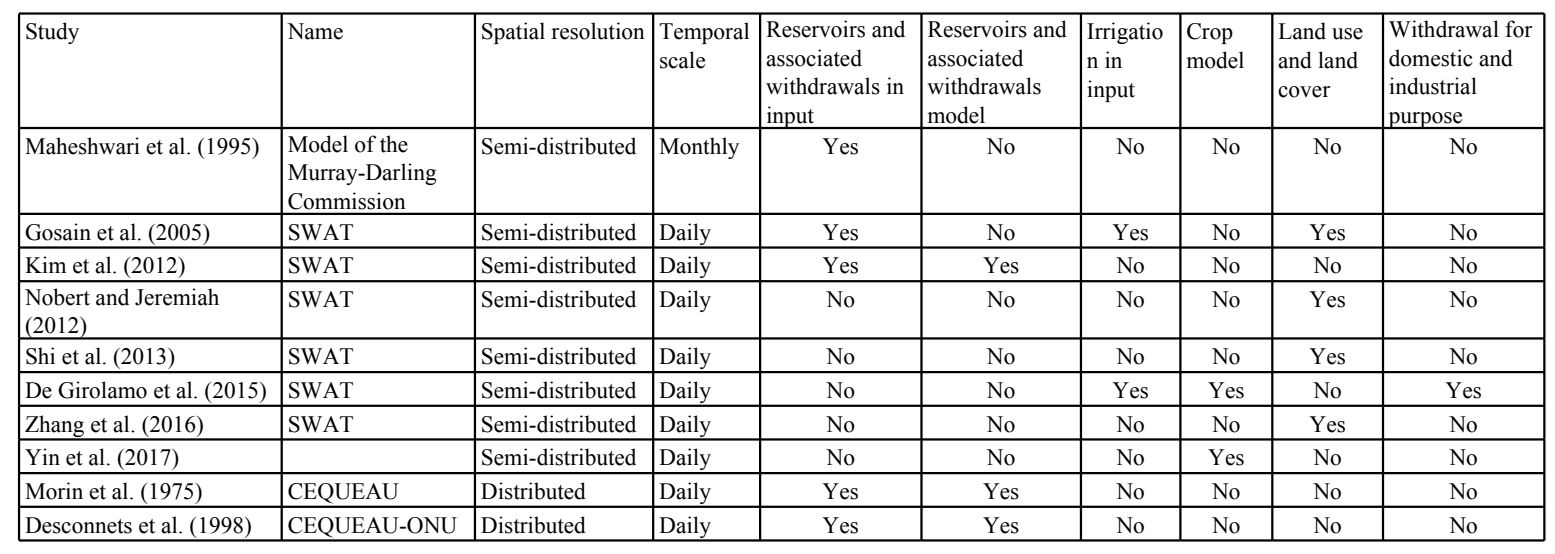




\begin{tabular}{|c|c|c|c|c|c|c|c|}
\hline Authors & Catchment & Country & Influence & Model & Time step & $\begin{array}{l}\text { Calibration } \\
\text { period }\end{array}$ & $\begin{array}{l}\text { Naturalization } \\
\text { period }\end{array}$ \\
\hline $\begin{array}{l}\text { Siriwardena et al. } \\
(2006)\end{array}$ & $\begin{array}{l}\text { Comet River basin (1 } \\
\left.400 \mathrm{~km}^{2}\right)\end{array}$ & Australia & $\begin{array}{l}\text { Land use and land cover } \\
\text { change }\end{array}$ & $\begin{array}{l}\text { SIMHYD (Chiew et } \\
\text { al., 2008) }\end{array}$ & Daily & $1970-2000$ & $1970-2000$ \\
\hline Wen (2009) & \begin{tabular}{|l|}
$\begin{array}{l}\text { Murrumbidgee river } \\
\left(84,000 \mathrm{~km}^{2}\right)\end{array}$ \\
\end{tabular} & Australia & $\begin{array}{l}\text { Fourteen dams and eight } \\
\text { large weirs }\end{array}$ & Regressive model & Monthly & $1889-1920$ & $1921-2007$ \\
\hline Ma et al.(2010) & \begin{tabular}{|l|} 
Junction of Chao and \\
Bai River basin \\
$\left(15,800 \mathrm{~km}^{2}\right)$
\end{tabular} & China & $\begin{array}{l}\text { Direct withdrawal for } \\
\text { irrigation and land use } \\
\text { changes }\end{array}$ & $\begin{array}{l}\text { GBHM (Yang et al. } \\
2002,1998)\end{array}$ & Hourly & $1956-1965$ & $1984-2005$ \\
\hline Wang et al. (2010) & $\begin{array}{l}\text { Baimasi basin } \\
\left(13,915 \mathrm{~km}^{2}\right) \\
\text { Yellow River }\end{array}$ & China & $\begin{array}{l}\text { River water withdrawals for } \\
\text { irrigation, land use changes }\end{array}$ & $\begin{array}{l}\text { VIC model (Liang et } \\
\text { al., 1994) }\end{array}$ & Daily & $1961-1970$ & $1971-2000$ \\
\hline Jiang et al. (2011) & $\begin{array}{l}\text { Laohahe basin } \\
\left(18,112 \mathrm{~km}^{2}\right)\end{array}$ & China & $\begin{array}{l}\text { Agricultural and industrial } \\
\text { withdrawals, dams and } \\
\text { reservoirs }\end{array}$ & $\begin{array}{l}\text { 1. Multi-regression } \\
\text { 2. VIC model }\end{array}$ & $\begin{array}{l}\text { 1. Monthly } \\
\text { 2. Daily }\end{array}$ & 1964-1979 & $1980-2008$ \\
\hline Bao et al. (2012) & $\begin{array}{l}\text { Three catchments of } \\
\text { the Haihe River } \\
(\text { from } 1,800 \text { to } \\
24,000 \mathrm{~km}^{2} \text { ) }\end{array}$ & China & $\begin{array}{l}\text { Surface water and } \\
\text { groundwater withdrawals } \\
\text { for farm, industry and } \\
\text { population and land use } \\
\text { changes }\end{array}$ & $\begin{array}{l}\text { VIC model (Liang et } \\
\text { al., 1994) }\end{array}$ & Daily & $\begin{array}{l}11 / 16 \text { years } \\
\text { in the } 1952- \\
1972 \text { period }\end{array}$ & $\begin{array}{l}5 / 40 \text { years in } \\
\text { the } 1965-2004 \\
\text { period }\end{array}$ \\
\hline Wang et al. (2013) & $\begin{array}{l}\text { Haihe River basin } \\
\left(189,000 \mathrm{~km}^{2}\right)\end{array}$ & China & $\begin{array}{l}\text { Surface water and } \\
\text { groundwater withdrawals } \\
\text { for farming, industry and } \\
\text { population and land use } \\
\text { changes } \\
\end{array}$ & $\begin{array}{l}\text { Two-parameter } \\
\text { monthly hydrological } \\
\text { model (Xiong and } \\
\text { Guo, 1999) }\end{array}$ & Monthly & $1957-1978$ & $\begin{array}{l}1978 / 1980- \\
2000\end{array}$ \\
\hline Zhan et al. (2013) & Bai River $\left(9,228 \mathrm{~km}^{2}\right)$ & China & Dams, farmland & $\begin{array}{l}\text { SIMHYD (Chiew et } \\
\text { al., 2008) }\end{array}$ & Daily & $1986-1990$ & 1991-1998 \\
\hline $\begin{array}{l}\text { Ahn and Merwade } \\
(2014)\end{array}$ & $\begin{array}{l}103 \text { Stations in New } \\
\text { York, Indiana, } \\
\text { Arizona and Georgia }\end{array}$ & USA & & $\begin{array}{l}\text { Regression (Jiang et } \\
\text { al., 2011) }\end{array}$ & Monthly & $1950-1979$ & $1981-2010$ \\
\hline Guo et al. (2014) & $\begin{array}{l}\text { Weihe River }(30,661 \\
\left.\mathrm{km}^{2}\right)\end{array}$ & China & $\begin{array}{l}\text { Agricultural irrigation, } \\
\text { industrial development, dam } \\
\text { construction }\end{array}$ & HBV model & Daily & $1972 / 1975-19$ & $1985-2007$ \\
\hline Chang et al. (2015) & $\begin{array}{l}\text { Jinghe River basin } \\
\left(45,400 \mathrm{~km}^{2}\right)\end{array}$ & China & Withdrawals & $\begin{array}{l}\text { 1.TOPMODEL } \\
\text { 2.VIC model (Liang } \\
\text { et al., 1994) }\end{array}$ & $\begin{array}{l}\text { 1. Monthly } \\
\text { 2. Daily }\end{array}$ & $1960-1970$ & $1971-2010$ \\
\hline
\end{tabular}




\begin{tabular}{|c|c|c|c|c|}
\hline Authors & Catchment & Country & Influence & Model \\
\hline $\begin{array}{l}\text { Peters and Prowse } \\
(2011)\end{array}$ & $\begin{array}{l}\text { Lower Peace } \\
\text { River }(293000 \\
\left.\mathrm{km}^{2}\right)\end{array}$ & Canada & Hydroelectric dam & $\begin{array}{l}\text { Hydraulic: one-dimensional } \\
\text { hydraulic flood routing model }\end{array}$ \\
\hline Ahn et al. (2006) & Illinois river & United States & $\begin{array}{l}\text { Seven locks and dams, } \\
36 \text { levees }\end{array}$ & Hydraulic (UNET) \\
\hline Peters et al. (2006) & $\begin{array}{l}\text { Peace-Athabasca } \\
\text { Delta }\left(6000 \mathrm{~km}^{2}\right)\end{array}$ & Canada & Hydroelectric dam & $\begin{array}{l}\text { Hydraulic: one-dimensional } \\
\text { hydrodynamic model }\end{array}$ \\
\hline $\begin{array}{l}\text { Shiklomanov and } \\
\text { Lammers (2009) }\end{array}$ & $\begin{array}{l}\text { Large Russian } \\
\text { Arctic rivers } \\
\end{array}$ & Russia & Reservoirs & $\begin{array}{l}\text { Hydraulic: hydrograph routing } \\
\text { model }\end{array}$ \\
\hline $\begin{array}{l}\text { Wyrick et al. } \\
(2009)\end{array}$ & $\begin{array}{l}\text { Mantua Creek (19 } \\
\left.\mathrm{km}^{2}\right) \text {, New Jersey }\end{array}$ & United States & Two small dams & $\begin{array}{l}\text { Hydraulic (HEC-RAS) + } \\
\text { Hydrology (HEC-HMS) }\end{array}$ \\
\hline Wu et al. (2015) & Taiwan $\left(680 \mathrm{~km}^{2}\right)$ & Taiwan & $\begin{array}{l}\text { Reservoirs and } \\
\text { diversions }\end{array}$ & \\
\hline
\end{tabular}




\begin{tabular}{|c|c|c|c|c|c|c|c|}
\hline & Data required & $\begin{array}{c}\text { Water } \\
\text { Balance }\end{array}$ & Reconstitution & Extension & $\begin{array}{c}\text { Paired } \\
\text { Catchment }\end{array}$ & Neighbourhood & $\begin{array}{c}\text { Routing } \\
\text { modelling }\end{array}$ \\
\hline \multirow{5}{*}{ 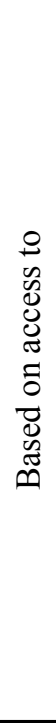 } & \multirow{2}{*}{$\begin{array}{l}\text { Influenced period } \\
\text { information: } \\
\text { Influenced observed } \\
\text { streamflow } \\
\text { Influence volume time } \\
\text { series }\end{array}$} & $X$ & $\mathrm{X}$ & & & & \\
\hline & & $\mathrm{X}$ & $\mathrm{X}$ & & & & \\
\hline & $\begin{array}{l}\text { Uninfluenced period } \\
\text { information: } \\
\text { Natural observed } \\
\text { streamflow on a pre- or } \\
\text { postinfluence period } \\
\end{array}$ & & & $\mathrm{X}$ & $\mathrm{X}$ & & \\
\hline & \multirow{2}{*}{$\begin{array}{l}\text { Regional information: } \\
\text { - Upstream natural flow } \\
\text { - Natural observed } \\
\text { streamflow on } \\
\text { neigboorhoud catchment }\end{array}$} & & & & $\mathrm{X}$ & $\mathrm{X}$ & $\mathrm{X}$ \\
\hline & & & & & $\mathrm{X}$ & $\mathrm{X}$ & \\
\hline \multirow{3}{*}{ 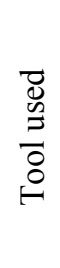 } & Hydrological model & & $\mathrm{X}$ & $X$ & $X$ & $\mathrm{X}$ & \\
\hline & Hydraulic model & $\mathrm{X}$ & & & & & $\mathrm{X}$ \\
\hline & $\begin{array}{l}\text { Mass balance method } \\
\text { (catchment area scaling, } \\
\text { equipercentile methods, } \\
\text { etc.) }\end{array}$ & $\mathrm{X}$ & & & & & \\
\hline
\end{tabular}




\begin{tabular}{|c|c|c|c|c|c|c|c|c|c|}
\hline \multirow{2}{*}{ Index } & \multirow{2}{*}{ Catchments } & \multirow{2}{*}{ Area $\left[\mathrm{km}^{2}\right]$} & \multirow{2}{*}{ Influences } & \multicolumn{4}{|c|}{ Naturalization method } & \multirow{2}{*}{ Models } & \multirow{2}{*}{ Reference } \\
\hline & & & & WB & $\mathrm{R}$ & E & $\mathrm{N}$ & & \\
\hline 1 & La Cance & $\begin{array}{l}\text { From } 11 \text { to } \\
380\end{array}$ & Withdrawals and discharges, and farm dams & $\mathrm{X}$ & & & $\mathrm{X}$ & GR2M & BRL Ingénierie (2014) \\
\hline 2 & Le Loup & 283 & Dam and withdrawals & $\mathrm{x}$ & & & $\mathrm{x}$ & Grloieau-pixel monthly model & $\begin{array}{l}\text { Département des Alpes-Maritimes } \\
\text { (2013) }\end{array}$ \\
\hline 3 & Les Gardons & $\begin{array}{l}\text { From } 69 \text { to } \\
2034\end{array}$ & $\begin{array}{l}\text { Withdrawal for water supply, agriculture and } \\
\text { industry, and dam }\end{array}$ & $\mathrm{X}$ & & & $\mathrm{x}$ & GR4J & BRL Ingénierie (2015) \\
\hline 4 & Basse vallée de l'Ain & 3630 & $\begin{array}{l}\text { Five dams and, surface and groundwater } \\
\text { withdrawals }\end{array}$ & & $\mathrm{x}$ & & & Modflow & $\begin{array}{l}\text { SOGREAH Consultants et EPTEAU } \\
(2012)\end{array}$ \\
\hline 5 & Drôme des collines & 470 & Withdrawals & & $\mathrm{X}$ & & & $\begin{array}{l}\text { Conceptual semi-distributed } \\
\text { daily model }\end{array}$ & $\begin{array}{l}\text { Artelia Eau et Environnement et } \\
\text { Maison régionale de l'Eau (2012a) }\end{array}$ \\
\hline 6 & Hérault & 2622 & Withdrawals & & $\mathrm{x}$ & & & $\begin{array}{l}\text { ATHYS and hydrogeological } \\
\text { model with withdrawal module }\end{array}$ & $\begin{array}{l}\text { CEREG Ingénierie et Berga Sud } \\
(2015)\end{array}$ \\
\hline 7 & La Galaure & 240 & Withdrawals & & $\mathrm{X}$ & & & $\begin{array}{l}\text { Conceptual semi-distributed } \\
\text { daily model }\end{array}$ & $\begin{array}{l}\text { Artelia Eau et Environnement et } \\
\text { Maison régionale de l'Eau (2012b) }\end{array}$ \\
\hline 8 & Lez provençal & $\begin{array}{l}\text { From } 110 \text { to } \\
455\end{array}$ & $\begin{array}{l}\text { Surface and groundwater withdrawals for } \\
\text { irrigation and water supply }\end{array}$ & & $\mathrm{x}$ & & & $\begin{array}{l}\text { Hydrological model (ATHYS) } \\
\text { and hydrogeological model } \\
\text { (MODFLOW) with } \\
\text { withdrawal module }\end{array}$ & CEREG Ingénierie et al. (2013) \\
\hline 9 & Ouche & 916 & Surface and groundwater withdrawals & & $\mathrm{X}$ & & & \begin{tabular}{|l|} 
Semi-distributed model \\
\end{tabular} & SOGREAH et al. (2011) \\
\hline 10 & \begin{tabular}{|l|} 
Tille \\
\end{tabular} & 1300 & \begin{tabular}{|l|} 
Surface and groundwater withdrawals \\
\end{tabular} & & $\mathrm{X}$ & & & \begin{tabular}{|l} 
NAM (MIKE11) \\
\end{tabular} & SAFEGE Ingénieurs Conseils (2011) \\
\hline 11 & L'Asse & 692 & Withdrawals & & $\mathrm{X}$ & & $\mathrm{x}$ & $\begin{array}{l}\text { ATHYS with withdrawal } \\
\text { module }\end{array}$ & CEREG Ingénierie (2011) \\
\hline 12 & La Berre drômoise & 138 & Withdrawals & $\mathrm{x}$ & & & & & $\begin{array}{l}\text { Socièté du Canal de Provence et } \\
\text { ASCONIT Consultants (2012) }\end{array}$ \\
\hline 13 & L'Agly & \begin{tabular}{|l} 
From 157 to \\
1100
\end{tabular} & Surface and groundwater withdrawals, and dam & $\mathrm{x}$ & & & & & $\begin{array}{l}\text { GINGER Environnement \& } \\
\text { Infrastructures (2012a) }\end{array}$ \\
\hline 14 & Le Sègre & & $\begin{array}{l}\text { Withdrawals for irrigation, water supply, } \\
\text { industry and artificial snow, and hydroelectric } \\
\text { dam }\end{array}$ & $\mathrm{x}$ & & & & & SOGREAH (2012) \\
\hline 15 & Le Vidourle & 800 & Surface and groundwater withdrawals, and dams & $\mathrm{x}$ & & & & & $\begin{array}{l}\text { GINGER Environnement \& } \\
\text { Infrastructures (2012b) }\end{array}$ \\
\hline 16 & Les Usses & 310 & Withdrawals & $\mathrm{x}$ & & & & & $\begin{array}{l}\text { Risques et Développement et Maison } \\
\text { régionale de l'Eau (2012) }\end{array}$ \\
\hline 17 & Savoureuse & 235 & Withdrawals and farm dams & $\mathrm{X}$ & & & & & Cabinet Reilé (2012) \\
\hline 18 & Le Garon & 208 & $\begin{array}{l}\text { Groundwater withdrawals, farm reservoirs, inter- } \\
\text { basin transferts, dam, irrigation }\end{array}$ & $\mathrm{x}$ & & $\mathrm{X}$ & & GR2M & BRL Ingénierie (2013) \\
\hline 19 & Yzeron & 150 & 130 farm dams, inter-basin transfert, irrigation & $\mathrm{X}$ & 0 & $\mathrm{X}$ & & GR2M & BRL Ingénierie (2012) \\
\hline 20 & Le Doux & 630 & $\begin{array}{l}\text { Withdrawals and discharges, dams and farm } \\
\text { reservoirs }\end{array}$ & $\mathrm{X}$ & & $X$ & & GR4J & ISL (2011) \\
\hline 21 & La Cèze & 1359 & $\begin{array}{l}\text { Withdrawal for water supply, agriculture and } \\
\text { industry, and dam }\end{array}$ & $\mathrm{x}$ & & $\mathrm{x}$ & & GR2M & BRL Ingénierie (2011) \\
\hline
\end{tabular}

